\title{
$2 \mathrm{G} 01$ 集団検診および人間ドックにおける体脂肪率測定の意義（第 3 報）
}

石井一、山口 学、松井遵一郎、渡辺善二郎、大河内浩之 鹿島厚生病院 内科 外科 眼科

\section{集団検診 肥満 体脂肪率}

〈緒言〉我々はこれまで、体脂肪率の測定が、 成人病（生活習慣病）の危険因子を考虑する 際に有用な指標であることを報告した。そこ で我々は、継時的な体脂肪率の変化が血糖、 血圧および脂質の変化に及ぼす影響について 検討した。

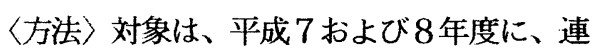
続して当院で検診もしくは人間ドックを受診 した症例で、体脂肪率を測定し得た成人男性 205 名であった。早朝空腹時に、身長、体 重および血圧を測定後、採血し、空腹時血糖 (F B S )、総コレステロール $(\mathrm{T} \mathrm{C}) 、 \mathrm{H}$ D L コレステロール（HDL）および中性脂 肪（T G）を測定した。体脂肪率は、夕二夕 T B F-102を用いてB I A法にて測定し
た。各種パラメーターの平成 8 年度値と平成 7 年度值の差について、比較検討した。 〈結果〉表に示すごとく、体重増加群では、 TCおよびT Gが上昇しHD L が低下、脂肪 率上昇群では S B P と T Cが上昇、BM I お よび肥満度上昇群では T Gが上昇、 HD Lが 低下した。

〈結論〉これまでの肥満の指標である、体重、 BM I および肥満度の継時的な低下では、脂 質の改善のみ認めたが、体脂肪率低下群では 脂質に加え、収縮期血圧の改善も認めた。よっ て、検診および人間ドックにおいて体脂肪の 測定を行い、体脂肪率が高い症例に対しては 体重のみならず体脂肪を念頭に置いた滅量指 導を行うことが重要である。

\begin{tabular}{|c|c|c|c|c|c|c|c|c|}
\hline & & $\mathrm{n}$ & $\triangle F B S$ & $\triangle \mathrm{SBP}$ & $\triangle \mathrm{DBP}$ & $\Delta \mathrm{TC}$ & $\triangle \mathrm{HDL}$ & $\Delta \mathrm{TG}$ \\
\hline 体 & $\begin{array}{l}\text { 減 } \\
\text { 少 }\end{array}$ & 100 & $-4.0 \pm 13.9$ & $1.2 \pm 15.2$ & $-5.8 \pm 10.4$ & $-4.2 \pm 23.7$ & $1.4 \pm 7.5$ & $-20.7 \pm 82.2$ \\
\hline 重 & $\begin{array}{l}\text { 増 } \\
\text { 加 }\end{array}$ & 105 & $-3.5 \pm 9.8$ & $1.5 \pm 14.8$ & $-4.2 \pm 12.8$ & $\begin{array}{r}* * \\
4.4 \pm 27.5 \\
\end{array}$ & $\begin{array}{r}* \\
-0.9 \pm 8.8\end{array}$ & $\begin{array}{r}* * \\
34.0 \pm 100.3 \\
\end{array}$ \\
\hline 脂 & 低 & 94 & $-4.9 \pm 13.1$ & $-2.3 \pm 15.3$ & $-5.2 \pm 12.1$ & $-6.6 \pm 22.4$ & $0.6 \pm 9.6$ & $-3.4 \pm 92.1$ \\
\hline $\begin{array}{l}\text { 肪 } \\
\text { 率 }\end{array}$ & $\begin{array}{l}\text { 上 } \\
\text { 昇 }\end{array}$ & 111 & $-2.8 \pm 10.8$ & $\begin{array}{r}* * \\
4.5 \pm 14.1 \\
\end{array}$ & $-4.8 \pm 11.4$ & $\begin{array}{r}* * \\
6.0 \pm 27.5 \\
\end{array}$ & $-0.2 \pm 7.0$ & $16.4 \pm 98.2$ \\
\hline B & 低 & 90 & $-3.0 \pm 14.2$ & $-0.5 \pm 14.9$ & $-6.1 \pm 10.4$ & $-3.1 \pm 24.7$ & $2.3 \pm 8.8$ & $-15.9 \pm 94.8$ \\
\hline $\begin{array}{c}M \\
\mathrm{I}\end{array}$ & 上 & 115 & $-4.3 \pm 9.8$ & $2.9 \pm 15.0$ & $-4.1 \pm 12.6$ & $2.8 \pm 26.8$ & $\begin{array}{r}* * \\
-1.5 \pm 7.5 \\
\end{array}$ & $\begin{array}{r}* * \\
25.5 \pm \quad 92.9 \\
\end{array}$ \\
\hline 肥 & 低 & 88 & $-3.0 \pm 13.6$ & $-0.7 \pm 14.9$ & $-6.3 \pm 10.4$ & $-3.2 \pm 24.8$ & $2.3 \pm 8.9$ & $-18.0 \pm 94.0$ \\
\hline $\begin{array}{l}\text { 満 } \\
\text { 度 }\end{array}$ & 上 & 117 & $-3.9 \pm 10.6$ & $3.0 \pm 14.9$ & $-4.0 \pm 12.5$ & $2.7 \pm 26.7$ & $\begin{array}{r}* * \\
-1.4 \pm 7.4 \\
\end{array}$ & $\begin{array}{r}* * \\
26.4 \pm 92.9 \\
\end{array}$ \\
\hline
\end{tabular}




\section{$2 \mathrm{G} 02$ 大腸集検の精検状況}

イガラシ キヨシ

五十風架 桑原敏行 中島康 伊藤秀幸 ${ }^{1 ）}$ 上坂佳敬 ${ }^{2}$ 高橋和則 佐藤幸二3）佐藤正二郎 ${ }^{4 ｝ \text { （仙北組合総合病院 消化器科1） }$ 病理診断科2）臨床検査科 3 (保健活動室 ${ }^{4 ）}$ )

大腸集検 精検状況 便潜血 cut off 值

\section{〈はじめに〉}

大曲市および仙北郡は、秋田県の県南部に位 置する人口約 16 万人農村地域である。当地 域においても、平成 5 年度より、老健法に基 ゔいた大腸集検がほぼ一斉にスタートした。 一次検診は、1 1 市10町村では秋田県保健事業 団が、3 町では秋田厚生会から委託された当 院で行っている。便潜血検査は両施設とも $\mathrm{OC}$ ヘモディア (cut off 値100ng/ml) 2 日法である。 当地域内の二次検診の精検実施機関は、6病 院、17診療所の合計23施設である。当地域に おける平成 5 年から 7 年度の精検受診状況、 及び当院の精検状況、成績について報告する。

〈結果〉 1）当院の大腸検査件数は年々増加 し、平成 4 年からは、大腸内視鏡検查は昭和 63 年の約 4 倍の年間約 2000 件、注腸 X線検查 は約 2 倍の年間約 1000 件に急増している。

2) 大腸検査件数を月別にみると、7 月から 9 月の夏場は、冬場 1 月から 3 月の約 3 倍で あった。

3) 当地域の検診対象者数は、平成 5 年 51,081 人、平成 6 年 55,816 人、 7 年では 56,535 人で、一次検診の受診率は、平成 5 年 $41.1 \%$ 、 6 年 $46.3 \% 、 7$ 年 $46.2 \%$ で、平均 $44.6 \%$ であっ た。要精検率は、平成 5 年 $10.0 \% 、 6$ 年 $6.7 \%$ 、 7 年 $7.4 \%$ で、平均 $7.9 \%$ であった。精検受診者 数、精検受診率は、平成 5 年 1,433 人、 $68.7 \%$ 、 6 年 1,260 人、 $73.3 \% 、 7$ 年 1,366 人、 $71.1 \%$ で あった。この中で、当院で精検を受けた人は、 平成 5 年 437 人、 6 年 457 人、 7 年 514 人の計 1,408 人で、当地域の全精検者数に占める割合 は平均 $34.7 \%$ であった。

4 ) 市町村別の精検受診率をみると、精検施 設の多い大曲市では78.9\%と、全市町村の平 均70.9\%を上回っていた。精検施設のない 6 町村では、4 町村で平均より低かったが、残 り 2 つの村では、80.0\%、76.5\%と高率であっ た。
5 ）当院で 3 年間に行った 1,408 人の精検方法 についてみると、一次精検として $1,029 人 73.1$ $\%$ S 状内視鏡検查と注腸 X線検查の併用法 による検査が行われた。最終的には、604人 42.9\%に全大腸内視鏡検查が行われた。

6) 3 年間の発見癌症例数は87例で、精検受 診者に占める割合は6.2\%であった。ポリープ は359例 $25.5 \%$ に発見された。

7 ) 当院で一次検診を行っている 3 町での癌 発見率は $0.25 \%$ あった。

8 ）当院の検診成績をむとに、便潜血半定量 のcut off值を変更した場合のシュミレーショ ンをすると、cut off 值を150ng/mlにした場合、 要精検率は $5.3 \%$ 、癌発見率は $0.23 \%$ 、

$200 \mathrm{ng} / \mathrm{ml}$ にした場合、要精検率は $4.0 \%$ 、癌発 見率は $0.21 \%$ あった。

〈結論〉当院での大腸検査件数は飛躍的に 増加し、特に、精検は夏場に集中して行われ た。当院での精検数は、処理能力の限界に近 く、夏場にこれ以上精検者数が増えると、検 查待ち期間を延長せざるを得ないのが現状で ある。精検受診率を上げるには、当地域にお ける精検機関の充実が必要と思われるが、現 実には難しく、実施主体である自治体の継続 した啓蒙活動、精検受診勧奖が重要であると 思われた。効率のよい大腸集検を行うために は、便潜血検查のcut off 值を上げ、要精検率 を抑制することも、今後検討すべきことと考 えられた。 
2G03 広域保健センターにおける健診システムについて

\author{
徳丸文康 吉留畺二 宮川麗子 \\ 入佐孝三 吉富、誠 竹熊宜孝 \\ （菊池広域保健センター・ 公立菊池養生園診療所）
}

集団健診 健診システム

<緒言〉 熊本県菊池郡市内 6 市町村で運営 されてきた公立菊池養生園診療所に、平成 4 年 3 月広域保健センターが併設された。その 際、健診の効率化之健診データの有効活用を 目的に、電算による健診システムを導入した。 5 年間の実績をもとに、システム導入の成果 と今後の課題を検討したので報告する。 〈方法> 管内人口99,000人の保健七 ンターで実施している健診は、老人保健法に よる基本健診、人間ドック（日㷌り、宿泊、 政府管掌)、肺ガン、結核、大腸ガン、労倠 安全衛生法による根場健診、政府管掌一般健 診、特殊健診など 14 種にわたる。受診者数 は、年間のべ 45,000 人である。

システム導入の方針は、(1)健診者登録及び 受付をできるだけ簡単に行えるようにする。 (2)健診結果の入力の迅速化をはかる。(3)結果 判定の自動化を推進する。(4)健診結果の統計 処理を充実させる。(5市町村、県への健診テ 一夕の移行を簡便に、安洒に行えるようにす る。(6)個人データの経年変化が容易にわかる システムをつくることなどである。

具体的には、(1)受診者の登録受付について 6 市町村の 15 歳以上の全住民の受診者リス 卜を各市町村基本台棖をもとに作製し年 2 回 更新しそれ以外の受診者は、事前に登録する か健診当日に受付時での登録も可能とした。 (2)受診票の発行については、各市町村で各種 健診の受付票を発行する場合は、住民基本台 帪 I Dを使用した。これによって、登録者に
固有の I Dを自動的に付与できるようになっ た。健診は施設内健診中心で施設外の場合は、 O C R 用紙を用いて自動登録した。一部は手 入力も行っている。

＜結果＞ (1)管内居住者については、事前登 録が必要なく、受付時に容易に登録ができる ようになった。住民の移動があっても登録の 更新で容易に対処できた。(2)個人の受診履歴 が、一元的に管理できて、異なる健診を受け ていても、すべての受診結果が容易に画面上 にだせる。(3)同一健診の結果が時系列で表示 できるので、肺ガン検診の比較読影等で、フィ ルム等の選択が容易にできるなど、事務効率 の向上が格段にはかられた。(4)市町村へのデ 一夕の移行が容易になった。また、事業所や 市町村が、県や関俰機関に提出するための統 計や一覧表も同時に眍布できるようになった。 (5)外来を受診した際、過去のデー夕も十分活 用できるようになった。(6)要精密者、未受診 者などの抽出が容易にできて、保健事後指導 等にも効果がみられた。

〈結詥〉 新しいシステムによって、受診 者の登録、受付、結果の管理、デー夕の統計、 保健指導などへの応用で効率化、簡素化がは かられた。今後の課題としては、現在MTに よるテータの移行で十分対応できるが、将来 的には、市町村、医療機関、県とのオンライ ン化を視野に入れたシステムの構筑も必要と 思われた。 
$2 \mathrm{G} 04$ 人間ドック精査指示率とその内容を検討して

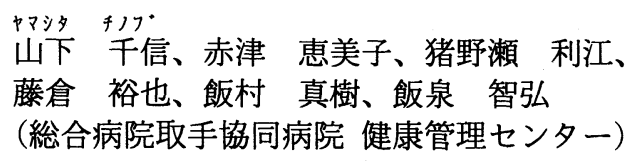

人間ドック 追跡調查精査指示率

\section{《はじめに》}

当センターでは、平成 7 年は、要精査者を対 象として受診後の follow - upに力をいれ、精 査実施率 $60.7 \%$ という結果を得た。しかし、 当院における精查指示率は $83.0 \%$ 、全国平均 の $47.6 \%$ 上回っていた。今回項目別精査指示 率とその内容を調べ、この問題について検討 した。

\section{《対象および方法》}

予防医学委員会報告による、全国 1 泊 2 日人 間ドック実施病院の実態調査（平成 7 年）・同 集計成績をもとに、当院平成 7 年ドック受診者 総数 1069 名の、項目別精查指示率とその内容 を検討した。

\section{《結果および考察》}

当院項目別 (精査指示率) と〈実施率〉は
1）上部消化管
(26. $0 \%)$
$\langle 62.9 \%\rangle$
2）検尿
(20.7\%)
$\langle 73.4 \%\rangle$
3）心電図
(18. $0 \%)$
$\langle 61.5 \%\rangle$
4) 脂質代謝異常
(17. 7\%)
〈未調査〉
5) 肝機能異常
(15. 7\%)
〈未調査〉

の順であった。

当院の上位 3 項目について検討した。

1. 上部消化管では、胃癌が 3 名発見されてお

り、胃癌発見率は $0.28 \%$ で全国平均の $0.08 \%$ を上回っていた。異常なしが 4 名、胃炎・胃ポ リープ・潰瘍等が認められた。

画像検查においては、統一した判定基準が難し く、判定医師により要精查指示率にも相違があ り、当院では読影の際に少しでも疑わしい時
は、積極的に精査の指示を出しており、全国平 均より高率であった。それでも、要精査指示者 はなお多く、これを減少させるため、前回の受 診結果を添付するなどの情報提供をすること が必要であると思われる。

2. 検尿では、要精查の内訳は、潜血・尿沈査・ 白血球・蛋白・比重・尿糖の順であった。潜血 118 名のうち赤血球サイズを測る R DW検査は 33 名に施行でき、小球性が 28 名であった。潜 血反応陽性の受診者すべてにこの検查を実施 し、判定に活用すれば、要精査指示者を減少さ せることが出来ると思われた。数量検査におい ては、判定基準を定めることは容易のようであ るが、個人のデータに合った判定を考慮するこ とが必要であると思われる。

3. 心電図では、要精査の内訳は、左室肥大・

$\mathrm{S} \mathrm{T}$ 変化・T波異常の順であった。

左室肥大（疑いも含む）が全体の $53.1 \%$ と高率 なのは、当院では左室肥大の判定基準に、精度 の高い Casale らの判定を使用しているためだ と思われた。

\section{《結論》}

今回、当院における精查指示率が $83.0 \%$ と高 率なので調べた結果、精査指示率を減少させる ための改善策が見つかった。

改善策を有効に使い、受診者に負担をかけない ような最大効果的指示が出されることが望ま しく、今後も受診者の立場になってデータの追 跡をし、判定医と密接なコミュニケーションを とっていきたい。 
2G05 平成 7 年度胃集団検診全国調査について

$\begin{array}{clrlll}\text { ○荒井 } & \text { 哲郎 } & \text { 片野 } & \text { 牧子 } & \text { 野田 } & \text { 邦夫 } \\ \text { 天神 } & \text { 正之 } & \text { 片木 } & \text { 康行 } & \text { 野口 } & \text { 正則 } \\ \text { (財)日本成人病予防会 } & & & \end{array}$

\section{胃集団検診全国調查}

(賏日本成人病予防会 (山瀬博理事長) は、農山村 地域住民に対する成人病予防対策の一貫として、 昭和 38 年設立以来、成人病巡回検診車・機器の整 備をはかり検診を行っている。この整備事業は、 日本自転車振興会 (宇賀道郎会長) 等の補助金によ るもので、特に成人病巡回検診車は平成 7 年度末 で延べ162台を整備した。このうち平成 7 年度に稼 働している各支部の検診車79台とX線テレビ装置 62台について胃集団検診の実態調査を行ったので 報告する。

〔検診車・機器の稼動状況等〕検診車79台の稼働 状況についてみると、1 台当り年平均稼㗢日数は 122.8 日、1 日平均検診人員は 38.5 人で、前年度の 39.9 人より 0.4 人減少した。なお、受診者一人当り の撮影フィルム枚数の平均は7.3枚、検診料金(胃 部のみ)の平均は $4,400.9$ 円となっている。また、 $\mathrm{X}$ 線テレビ装置の撮影フィルム枚数の平均は 9.8 枚、検診料金の平均は10,324.1円となっている。

〔検診者〕平成 7 年度の検診者総数は、 48 万 1,006 人で、男女別に構成割合をみると、男 22 万 4,633 人 (46.7\%)、女 25 万 6 , 373人 (53.3\%)となっており、 男は女の受診者より 3 万 1,740 人少ない。成人病検 診の主たる対象となる40歳以上の受診者数をみる と、男 19 万 2,386 人で 40 歳以上が $85.6 \%$ を占め、女 は 23 万 5 , 408人で $91.8 \%$ となっている。

〔要精検者〕検診者総数の $13.6 \% 、 6$ 万 5,192 人が 該当し、検診車のみを調查対象とした 6 年度の 13.3\%と比べて0.3ポイントの増加となっている。 男女別にみると男が $56.9 \% 、 3$ 万7, 123人に対して 女は $43.1 \%$ の 2 万 8,069 人であり、検診者総数の男 女比率とは逆に男が高くなっている。今後、男性 の受診を一層促進し、早期発見・早期治療に努め る必要があると考えられる。

また、40歳以上の検診者の要精検率は男 $19.3 \%$ 、
女 $11.3 \%$ 、全体では $14.1 \%$ となっており、検診者 全体の要精検率(男 $16.5 \%$ 、女 $5.8 \%$ ) と比較すると 女性が40歳を境に 2 倍近い伸びとなっている。

〔精検受診者〕要精検者の $67.2 \% 、 4$ 万 3,814 人が 受診した。男女別では、男が $62.1 \% 、 2$ 万3,070人 に対して女は $73.9 \% 、 2$ 万 0.744 人であり受診率は 女が男より 11.8 ポイント高い。

40 歳以上の精検受診率は $67.8 \%$ （男62.8\%、女 $74.2 \%)$ となっている。

〔胃がん患者〕胃がん患者数は614人(男425人、 女189人) で、検診者数に対する発見率は $0.128 \%$ ( 1,000 人当り 1.28 人) であり、検診車のみを調査 対象とした 6 年度の $0.113 \%(1,000$ 人当り 1.13 人) より高くなっている。男女別発見率 $(1,000$ 人当り) は、男 1.89 人にたいして女 0.73 人となっており、 男は女の約 2.6 倍と高い数值を示している。胃がん 患者 614 人のうち早期がんは、男 205 人、女 49 人、 計 304 人だった。

〔その他の疾病〕胃ポリープが5, 119人(発見率 1.1 \%)、胃潰瘍 4,151 人（同0.9\%）、十二指腸潰瘍 1,760 人(同0.4\%)、胃炎 9,780 人(同 $2.0 \%$ )などが 発見された。

〔課題〕以上の集計結果を踏まえて、(1)経年受診 を推進し、早期がんを発見する、(2)結果報告会を 充実し、特に男性を中心に精検受診率を高めるこ となどが必要と考えられる。

なお、昭和 58 年度調查と比較すると、(1)巡回検 診車による検診者数は 25 万 9,779 人から 37 万 3,274 人と大幅に増大した、(2)胃がん発見率は、1,000人 対比で 58 年度の 0.91 人から 7 年度 1.13 人（巡回検 診のみ）と、大幅に向上している。 
2G06 農業粉塵による呼吸器障害に関する研究一全国実態調査より一

根本浩一郎、浅沼信治、臼田誠、佐々木真爾

（日本農村医学研究所）

農業粉塵、呼吸器障害、過敏性肺炎

＜緒言＞ 農業従事者は、高熱性放線菌、真菌、 動物性タンパク、及び種々の粉鹿を吸入せざる を得ない環境にさらされている。欧米では、農 業に関連する呼吸器障害の報告は、1932年 よりなされている。一方、我が国においては、 その研究の歷史は比較的新しく、鎌田らが 19 74 年に農夫肺の存在を明らかにしている。

農業粉鹿による呼吸器障害について、農夫肺 等の過敏性肺炎が散在性に報告されてはいる ものの、最近の全国を対象とした疫学的な調査 報告は少ない。そこで我々は、農業粉塵による 呼吸器障害全国実態調查を実施した。最近 5 年間の症例数、地理分布、農夫肺の発症時期等 につき若干の知見を得たので報告する。

<方法＞全国の厚生連病院、診療所を対象とし、 過去5年間（概小 1990 年より 1994 年） に経験した農業粉塵による呼吸器障害の実態 調査を往復葉書を用いて行った。1994年 10 月 22 日に 130 通投函し、症例「有」と 返答のあった 7 医療機関に対して、再度調査票 を郵送し回答を得た。

$<$ 結果 $>87$ 通が返却され、「有」が 7 通（計 12 例)、「無」が 80 通だった。5年間の観 察期間の内、新規に発生した症例は 7 例だった。 12 症例中、個人調查票が返答された 11 例に つき検討を加えた。

診断名について：農夫肺 7 例、きのこ栽培者肺 3 例、わけぎ栽培者喘息（本邦発報告） 1 例が
報告された。

県別発生頻度: 北海道 5 例（全て農夫肺）、秋 田県 3 例、広島県 2 例、長野県 1 例であった。

喫煙：「有」 1 例、「無」 10 例であった。 発症時期 : 農夫肺に関して、夏季 4 例、秋季 3 例であった。

BAL所見：リンパ球増加が 7 例中 4例に見ら れた。CD 4/CD 8 上昇が4例に見られ、低 下が3例に見られた。

＜考察>咦煙について: 過敏性肺炎患者の鄙煙 率は対照者に比較して低く、抗原暴露を受けた 者の内、喫煙者の血清特異抗体価は、非喫煙者 よりも低い。喫煙が抗体産生系に抑制的に作用 することが示唆されている。今回の結果も従来 の報告と同様であった。

発症時期について:農夫肺は、冬季に多く発症 するとされているが、本研究ではこの傾向は伺 えなかった。理由の一つとして、近年輸入牧草 が多く用いられることが考えられた。

BAL所見について:農夫肺症例につき、症状 が進行するにつれて、CD4の産生量が増加し、 CD 4/CD 8が次第に上昇していく可能性 が考えられた。

<結論>今回の全国調査で得られた呼吸器障 害は 12 例であった。発症時期に関しては、農 夫肺の冬季発症は 1 例むなかった。 


\section{G07 農作業粉塺曝露者の真菌類による感作状況並びに粉塺防護に関する意識調査}

きしひろえ

岸宏栄、大浦栄次、小川忠邦、越山健二

（富山県農村医学研究会）

\section{農作業粉塵、真菌類ラスト、粉塵防護意識}

\section{はじめに}

富山県は、転作作物として大豆の収穫量 は常に全国上位を占めている。九州農試の 原慎一郎氏による富山産の大豆鞘 3 種類の 表面の真菌類の同定によると、全てよりク ラドスポリュウム、アルテルナリアが検出 された。今回、農村住民の真菌類による感 作状況について調査した。

また、農作業粉塵下で作業する者98名に ついて、マスクの着用の有無等について調 查し、快適なマスクの条件などについてア ンケート調査したので報告する。

\section{調査方法}

平成 7 年 1 月 2 月、富山県厚生連滑川 農村検診センターを受診した 497名の血清 の真菌類のクラドスポリュウム、アルテル ナリア、及びスギの R A S Tを行った。ま た、同センター受診者で農作業粉塵下の作 業従事者についてマスクの使用、未使用の 実態、快適なマスクの条件についてアンケ 一ト調查した。

\section{結果と考察}

R A S T 陽性者 (スコア 1 以上) は、クラ

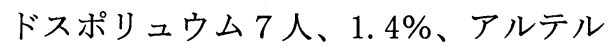
ナリア 6 人、 $1.2 \%$ 、スギ $21.1 \%$ であった。 農家、非農家別、農家で農作業粉塵作業従 事者、非従事者別でも感作状況に特に差は なかった。なお、クラドスポリュウム、ア ルテルナリア、スギの各 R A S T の陽性者 は相互に交叉性があった。以上より、富山 県の農村環境のもとにおける真菌類による 感作率は約 $1 、 2 \%$ あると考えられた。

農作業粉塵の多く発生する現場でマスク の着用率は、乾燥機内の掃除、大豆脱穀な どの作業に従事する者に高かった。望むマ スクは通気性のいいものも、着脱の容易な ものをあげる者が多かった。粉塵にはそれ ぞれ特徴があり、必ずしも目の細かいもの が必要でない場合も多い。それぞれの条件 に応じた防護法を考案する必要があると考 えられた。

\begin{tabular}{|c|c|c|c|c|c|c|c|c|c|c|c|c|c|c|}
\hline \multirow[t]{2}{*}{ No } & \multirow[t]{2}{*}{ 性 } & \multirow{2}{*}{$\begin{array}{l}\text { 年 } \\
\text { 路 }\end{array}$} & \multirow[t]{2}{*}{ 家業 } & \multirow[t]{2}{*}{ 農作業に従事しているか } & \multicolumn{3}{|c|}{ 栽培面積 (a) } & \multicolumn{2}{|c|}{ クラドスポリウム } & \multicolumn{2}{|c|}{ アルテルトリリ } & \multicolumn{2}{|c|}{ 双 } & \multirow[b]{2}{*}{ 農作業粉應の曝露 } \\
\hline & & & & & 水稻 & 大豆 & 野菜 & RAST & score & RAST & score & RAST & score & \\
\hline 1 & 男 & 36 & 兼業 & 日曜 - 休腵をとって従事 & 100 & 0 & 0 & 0.78 & 2 & 0.47 & 1 & 0.34 & 0 & 育苗床土調整, 粉鷹の多い豍燥場 \\
\hline 2 & 男 & 36 & 兼業 & 休日などたまに & 30 & 0 & 0 & 0 & & 0.55 & 1 & 0.56 & 1 & 粉塵なし \\
\hline 3 & 女 & 33 & 兼業 & しない & 100 & 0 & 0 & 0 & & 0.49 & 1 & 100.00 & 6 & 粉應なし \\
\hline 4 & 女 & 44 & 兼業 & 日曜・休暇をとって従事 & 40 & 0 & 5 & 1.32 & 2 & 0 & & 5.78 & 3 & その他粉應の多い作業 \\
\hline 5 & 女 & 49 & 専業 & 専業的に従事 & 600 & 0 & 30 & 0.35 & 1 & 0.35 & 1 & 0.65 & 1 & 粉塺の多い乾燥場 \\
\hline 6 & 女 & 53 & 兼業 & 日曜・休睱をとって従事 & 70 & 10 & 8 & 0.52 & 1 & 0 & & 0.34 & 0 & 粉應なし \\
\hline 7 & 男 & 43 & 非農家 & & 0 & 0 & 0 & 0.52 & 1 & 0.75 & 2 & 1.71 & 2 & \\
\hline 8 & 男 & 52 & 非農家 & & 0 & 0 & 0 & 0.49 & 1 & 0 & & 0.34 & 0 & \\
\hline 9 & 男 & 63 & 非農家 & & 0 & 0 & 0 & 2.26 & 2 & 2.1 & 2 & 0.34 & 0 & \\
\hline
\end{tabular}

大麦、花卉、チューリップ、果樹、野菜の栽培、牛、豚、鶏の飼育は、全員なし 
ハラダコウイチ

原田 幸一 1 、大森 昭子 1 、魏 長年 1 、有松 徳樹 2

上田 厚1

（熊本大 · 医 - 衛生 1 , 銀杏短期大学、衛生技術科 2 )

アルストロメリア、モルモット、感作性皮虐炎

＜緒言〉＼cjkstart切り花などとして栽培されるアル ストロメリアの取扱者のなかに接触性皮虐炎 がみられるという。その原因は、アルストロ メリアに含有されるアルカロイドである

Tuliposide-Aや、この加水分解物である $\alpha$ -

methylenebutyrolactone $(\alpha \mathrm{MBL})$ に接触すること であるといわれる。ところで、Magnusson and Kligmanは、モルモットを用い感作性皮膚障害 を検索するため、The guinea pig maximization test (GMT) を考案した。これは、優れた方法 であるが、結果が得られるには、時間がかか るので、アルストロメリア皮牊炎をGMTにて 検索した報告は少ない。そこで、我々は、 GMTにてアルストロメリアによる感作性皮膚 炎の確認をこころみた。また、GMTの修正法 であるRapid testを考案しアルストロメリアに よる皮膚感作性の迅速試験を試みた。さら

に、アルストロメリアの花、葉そして茎に含 まれる $\alpha$ MBLをHPLCにて定量し、皮蟹感作性: との関連をみた。

＜方法＞アルストロメリアのChristensen法抽 出物ならびに $\alpha \mathrm{MBL}$ 希釈液をハートレー系 雌モルモットの皮崩へ暴露し、一次刺激反応 を調べ、感作濃度と誘発濃度を決定した。つ きに、GMTに従ってFreund's complete adjuvant を用い皮嵅感作性試験を実行した。アルスト ロメリアのChristensen抽出物については抽出 原液の5倍希釈液にて感作し、10倍希釈液で誘 発した。 $\alpha$ MBLについては1\%溶液にて感作 し、0.1\%溶液にて誘発した。結果の判定およ びアレルギー性の区分に関してはGMTに提案 されている方法に従った。GMTの試験期間を 2週間ほど短くした、Rapid testによりアルスト ロメリアによる感作性皮微炎を調べた。アル
ストロメリアの花、葉および茎の各 $1 \mathrm{~g}$ を $4 \mathrm{ml}$ の水にとり、ポリトロンにてホモジナイズし たのち遠沈した。遠沈後その上清の漉過液を HPLCにて $\alpha \mathrm{MBL}$ な゙を測定した。

〈結果と考察〉 GMTによる部位別感作率を みると、 $\alpha \mathrm{MBL} 、$ 花、葉および茎抽出物によ る感作摔はそれぞれ100\%、92\%、75\%および 75\%であった。このときの感作の程度は、 $\alpha \mathrm{MBL}$ と花は、Extremeであり葉と茎はStrong であった。GMTによるアルストロメリア感作 性皮膚炎を確認した実験報告例があまりない ことを考えると、今回の結果は、興味ある知 見を提供するものである。Rapid Test での部位 別感作率は、 $\alpha M B L$ 花で $83 \%$ 、葉では $82 \%$ であり茎では、67\%であった。またこのとき の感作の程度は、 $\alpha \mathrm{MBL}$ 、花そして葉で

Extremeであり、茎でStrong であった。感作試 験に先だっておこなわれた皮虐刺激試験にお いて、高濃度のアルストロメリア抽出溶液な らび $\alpha$ MBLは、一次刺激作用を示すことが確 かめられた。アルストロメリア部位別の $\alpha \mathrm{MBL}$ の含有量は、花で $1.23 \pm 0.13 \mathrm{mg} / \mathrm{g}$-wetで あり最も高濃度であった。今後の課題は、抽 出物中感作物質の詳細な同定とアルストロメ リア皮䉐炎の予防対策を提示することであ る。

＜結論＞ GMTにて実験的にアルストロメリ ア感作性皮䖉炎を確認した。また我々が考案 したRapid testにより、GMTと同様にアルスト ロメリア感作性皮阅炎を確認した。また、ア ルストロメリア皮顝炎は感作性のみならず、 一次刺激性皮膚炎であることがわかった。 


\section{G09 山間部農村地域における家屋改造指導の実際}

長野県厚生連小諸厚生総合病院リハビリテーション科

井出佐都美 花岡利安 栗原かおる 日向康子 藤井道子 小林丈人 佐藤美智子 土屋匡 武井啓惠 水上弘史 金井涁 春原久幸

訪問指導・家屋改造

\section{【はじめに】}

農村地域の住宅構造は昔ながらの日本家屋 が多く狭小、段差、盢など障害者や老人にと って、必ずしも快適ではないことは容易に想 像できる。当院の診療圏である小諸北佐久地 域は、浅間山のすそ野に広がる山間部農村地 域で、傾斜、寒冷、未舗装道路といったこと も問題となっている。当院では退院前・後に 訪問を実施し実際の生活場所に出向き、家屋 改造指導を行っている。今回はこれらの経験 から、いくつか事例紹介的に報告する。

\section{【対象と方法】}

対象は 1990 年から 1996 年の 7 年間に当科 で訪問リハを行い、家屋改造指導を行った 293 名（男性 103 名、女性 190 名）を訪問記 録にもとづいて分析した。対象者の平均年齢 は $72.8 \pm 16.8$ 歳、疾患は脳血管障害、骨関節 疾患、脊髄損傷などである。

\section{【結果と考察】}

1,トイレ;トイレの改造が必要だと評価され たケースは 57.7\%であり、問題の無かったケ 一スは 22.5\%、オムツなどトイレの使用が必

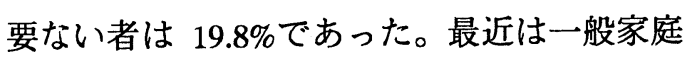
での洋式トイレの普及も進んでいるが、未だ 和式トイレの家庭は多かった。改造の内容と して最も多いのはトイレの洋式化であった。 昔ながらの家屋では、大便所と小便所のしき りを撤去する事によりワンルーム化してスペ 一スを確保する場合もあった。

2 , 浴室改造; 浴槽の改造が必要だと評価され
たケースは $51.2 \%$ 、必要無いケースは $8.8 \%$ 、

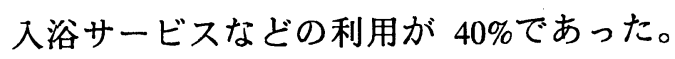
浴槽は半埋め込み式が使いやすいとされてい るが、公営住宅などは、置き型の浴槽も多か った。浴室の改造で最も多いのは、浴室用椅 子の設置であった。高さ $40 \mathrm{~cm}$ 程度のものを 用いるのが一般的で、市販されているが、ビ 一ルケースなどで代用すると安価であった。 また浴槽が深い場合、深さの補正には漬物用 の石がなめらかに加工してあり、取っ手も付 いていて重宝であった。

3,ベッド周囲;ベットは新規に必要なケース が 49.4\%、既存が 39.6\%、布団のままが $11 \%$ であった。改造は手すりの設置が最も多かっ た。ベッドの手すりは必要に応じて移動バー、 らくらく手すりなどを設置するが既製の手す りを鉄工所などでL字型に曲げてもらうと安 上がりであった。

4, 屋外へのアクセス; 現在の身体機能でどの ように屋外へ出るかは重要である。旧農家の 家屋構造では段差が多くスロープは欠かせな い。廊下スロープの設置は $11.3 \%$ 、玄関スロ

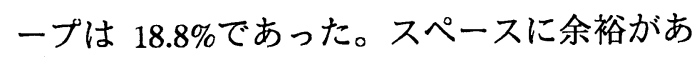
れば常設するが、取り外しができる耕䎣機の ブリッジなども紹介している。

\section{【まとめ】}

以上、いくつか事例紹介をした。病院や施 設においては、家庭生活を想定して指導して いるが限界があり、実際の現状を把握し生活 様式を考えていくことが必要と思われる。 
$2 \mathrm{G} 10$ 脳卒中片麻瘒患者の運動療法施行時の血圧変動について
和田範文 ${ }^{1)}$ 安田 洋 ${ }^{2)}$ 新井 正 $^{2)}$ 伊東祐二2)
早川和良 ${ }^{2)}$ 高屋忠丈 ${ }^{2)}$ 谷口小記子 ${ }^{1)}$ 辻本真紀 ${ }^{1)}$
西岡幸絵 ${ }^{1}$ 森井幸一 ${ }^{11}$ 岩越 優 ${ }^{1)}$ 樫木良友 ${ }^{3)}$
岐北総合病院リハビリテーション科 ${ }^{1)}$ 同内科 ${ }^{2)}$ 同外科 ${ }^{3)}$

\section{片麻瘏患者 血圧 運動療法}

【はじめに】片麻瘦患者の運動療法におけ るリスク管理は動悸，息切れなど主観的なも のが主で通常、経時的な脈拍，血圧の測定は 困難なことが多い。我々理学療法士が行なり 運動療法は、関節可動域訓練，筋力増強訓練 バランス訓練。起立歩行訓練などがあり、患 者に自動的あるいは他動的に適度な運動負荷 を与えながら、臥位から座位，立位レベルへ と段階的に展開して行くことが一般的である と考えられる。しかし、これらの運動負荷が 患者に及ぼす影響は多様と思われる。

今回我々は、運動療法施行中の片麻瘦患者 の経時的な血圧, 脈拍の変化を測定し、安静 時の血圧, 脈拍と比較検討を行なった。

【対象】当科で運動療法を施行中の片麻㾇 患者21例で急性期より 1 力月以上経過し、安 静時血圧の動摇が少ない男性12例，女性 9 例 で年齢中央值 66.7 歳, 平均訓練期間 8.3 月 であった。理学療法士がマンッーマンで行な 万訓練プログラムはほぼー定量の他動的, 自 動的運動を組み合わせたもので、訓練終了ま では約40分を要するものであった。

【方法】携帯型血圧連続測定装置を健側上 肢に装着し、訓練前に臥位, 座位, 立位の順 の3姿勢で各安静 5 分後の血圧を測定した。 訓練中は理学療法士が各患者に立案したプロ グラムを通常通り行ならことを原則として、 5分ごとに血圧，脈拍の測定を行なった。

【結果】(1)訓練前の安静時血圧は臥位より座 位，立位となるにしたがい収縮期血圧，拡張
期血圧ともに不变か上昇するものが多かった。 (2)運動療法施行中はすべての例で収縮期血圧, 拡張期血圧は上昇（上昇率約 $20 ３ 0 \%$ ）した が、必ずしも運動の強度とは相関しなかった。 また他動的, 自動的運動負荷での血圧の変化 に一定の傾向は認められなかった。

【考察】脳卒中片麻㾇患者に扎いての急激 な血圧上昇は、再発作防止の観点から重要と 思われる。特にこれら患者の運動療法では最 も注意が払われなければならない。

健常人に扎いては通常、運動の強度に比例 して血圧が上昇するが ${ }^{1)}$ 、今回我々が行なっ た片麻瘏患者の結果では、必ずしも運動の強 度や負荷での相関がなかった。ながは、訓 練開始值後や臥位での他動的な関節可動域訓 練で血圧の最高値を認めた例も存在した。

一般的に血圧の変動には、肉体的な運動負 荷のみならず、精神的なストレスやその日の 体調，気候，環境などの要因が挙げられるが、 片麻盘患者に扣いてはこれらの要因に加えて 諸動作の変化で容易に血圧が変動するものと 考只られた。以上のことより、我々理学療法 士が片麻痺患者にできるだけ質の高いレべル の運動療法を施行していくためには、諸動作 に伴う血圧の変動を十分に理解し、運動方法 を考虑していく必要があると思われた。

\section{【参考文献】}

1) 中村 正, 池田正春: 高血圧の運動療法.

臨床リ八 $3: 480-485,1994$. 
2G11 脳卒中女性患者の退院後における主婦業遂行状況

\section{艻藤修竞子}

（佐久総合病院リハビリテーション科）

脳卒中 主婦業 評価

【はじめに】当院で作業療法を受けている 脳卒中患者の中には、独居や夫婦二人暮しの ために、障害を抱えたまま主婦業を遂行せざ るを得ない女性患者も多い。

今回、我々は脳卒中女性患者の退院後にお ける主婦業遂行状况を把握するためにアンケ 一ト調査を実施した。その結果から、退院後 の主婦業遂行に必要と思われる指遵内容につ いて検討したので報告する。

【方法】平成 8 年 4 月 1 日より平成 9 年 3 月31日までに作業療法を処方された脳卒中 患者のうち、退院後も主婦業を遂行している 女性2 1名を対象とした。これらに担当作業 療法士が電話により主婦業遂行状兄を調査し た。

【結果】平成8年度に作業療法を処方され た脳卒中患者は160名、女性は61名（3

8.1\%)であった。上記の女性のうち「病 前に主婦業を遂行していた」のは36名 ( 5 9.0\%)、「現在も主婦業を遂行している 」は2 1名 (34.4\%)であった。この2 1名にアンケートを施行したところ「主婦業
を全て遂行している」のは11名、「一部援 助を得ながら遂行している」は 10 名であっ た。遂行か困難な主婦業は下記の表の通りで ある。それらを分析すると両手を使う動作、 特に協調動作、巧緻動作、目線より高いとこ ろでの作業、麻瘦側上肢に筋力を要する動作 であった。また、物を運搬しながらの作業、 しやがむなどのより高度なバランスを必要と した動作や、金銭管理等の問題解决能力を要 するものもあった。

【まとめ】 今回アンケート調査を行なった 結果、大半の主婦業が自立しているように見 えても、細部にわたる分析を行なうと、一部 介助を要する動作が多くみられた。それらの 問題を解決するためには、動作を細かく評価 し、患者個人にあった適切な指導、家族の援 助の仕方の指導、器具の紹介等、退院後に予 想される主婦業を見越した指導が不可欠であ る。また現在障害を抱えながらも主婦業を遂 行している患者からの情報提供も重要である と思われる。

\section{表 遂行力困難な主婦業}

\begin{tabular}{|c|c|}
\hline 調理 & ·野菜の千切り ·大きい鍋や食器の持ち運び ·鍋の摫拌・鍋の底の焦げを取る \\
\hline 掃除 & ·掃除機の操作·風呂の浴槽の底を洗う・布団の出し入れ·床の雑巾がけ \\
\hline 洗濯 & ·布団を干す·大きい洗濯物を干す・服をハンガーに掛ける \\
\hline 買物 & ・買物かごを持ちながら買物をする・予算を考えながら買物をする \\
\hline 裁縫 & 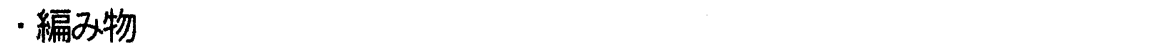 \\
\hline
\end{tabular}


2G12 脳梗塞と脳出血におけるリハビリテーションによる運動機能改善度の相違

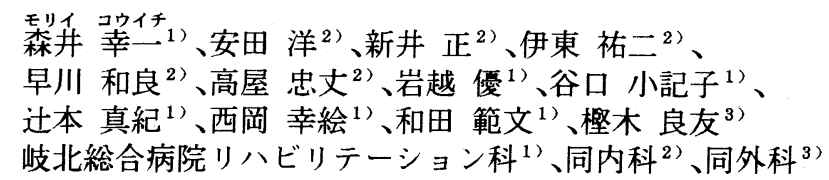

脳梗塞、脳出血、移動能力

【はじめに】脳血管障害には脳梗塞、脳内 出血、くも膜下出血があり、虚血之出血とい う病態の違いからその治療法も異なるが、こ れは脳循環の回復過程の相違と思われる。今 回我々は、リハビリテーション（以下リハと する）を積極的に行った脳血管障害患者を脳 梗塞と脳出血に分け、その移動能力の改善度 の相違について比較検討した。

【対象及び方法】1995年 1 月から1996年12 月までに当院に入院し、リ八を施行した脳血 管障害による片麻痺患者で、脳梗塞87名（男 性52名、女性 35 名、年歯中央値 70.7 歳）、脳 出血21名（男性 9 名、女性12名、年齢中央値 68.6歳）を対象とした。

脳血管障害発症急性期のリ八開始時之退院 時の移動能力をそれぞれ 0 : 坐位保持不能、 $1:$ 歩行不能（自力坐位とつかまり立ち）、 2 :介助歩行（監視下での屋内歩行）、3： 実用歩行と段階的に分類し各々の改善度をみ た。リ八施行期間は約 20 日〜 100日であった。

【結果】リ八開始時移動能力 $2 、 3$ の患者 についてはその改善度においては、脳梗塞・ 脳出血患者に差は認められなかったが、開始 時移動能力 $0 、 1$ の患者においては、脳出血 患者では 2 段階以上改善したものが多いのに 対して脳梗塞患者では少ない傾向にあった

（表 1）。

【考察】最近になり特に脳梗塞患者の増加 が多く認められるようになった。これは危険 因子としての環境、食生活の変化に伴い、高
脂血症、糖尿病、高血圧等の動脈硬化を促進 させる因子の増加のためと思われ、特に糖尿 病患者においては脳梗塞が多いと考えられる。 今回我々は、脳梗塞と脳出血におけるリ八 の改善度を検討したが、脳梗塞患者は脳出血 患者に比してリ八による改善の程度が悪いと 考えられた。これは、脳出血患者においては 急性期を過ぎると出血部周辺の脳浮腫が早期 に軽减され、脳に対しての損傷の程度が比較 的軽度に終わるためと思われる。これに対し、 脳梗塞患者においては広範囲な脳動脈の硬化 により急性期をすぎてもその損傷部位におい て長時間にわたり虚血が存在するために脳組 織の損傷の程度が大きくなると考えられた。

表 1 . 脳梗塞 - 脳出血患者の移動能力改善度

\begin{tabular}{|c||c||c|}
\hline \multicolumn{1}{|c|}{ 開始時 $\rightarrow$ 退院時 } & 脳梗塞 & 脳出血 \\
\hline $0 \rightarrow 0$ & 10名 (47.6\%) & 2名 (28.5\%) \\
$0 \rightarrow 1$ & 3名 (14.2\%) & 1名 (14.2\%) \\
$0 \rightarrow 2$ & 5名 (23.8\%) & 3名 (42.8\%) \\
$0 \rightarrow 3$ & 3名 (14.2\%) & 1名 (14.2\%) \\
$1 \rightarrow 1$ & 3名 (11.1\%) & \\
$1 \rightarrow 2$ & 13名 (48.1\%) & 2名 (28.5\%) \\
$1 \rightarrow 3$ & 11名 (40.7\%) & 5名 (71.4\%) \\
$2 \rightarrow 2$ & 5名 (20.8\%) & 1名 (25.0\%) \\
$2 \rightarrow 3$ & 19名 (79.1\%) & 3名 (75.0\%) \\
$3 \rightarrow 3$ & 15名 (100\%) & 3名 (100\%) \\
\hline
\end{tabular}

【参考文献】

1)田崎 義昭他: 神経病学、医学書院、1992.

2)和田 範文他: 片麻痺患者の退院時移動能力 に関する検討、岐厚医誌、第15巻、1994. 
2 G13 農山村地域における女性の貧血と鉄摂取

ツボイタカフミ

坪井敬文 ${ }^{1}$ 、鳥居本美 ${ }^{1}$ 、平井和光 ${ }^{2}$

(愛媛大・医・寄生虫 ${ }^{1}$ 、鳥取大・医・医動物 ${ }^{2}$ )

貧血、食生活、食品群別鉄摂取量

近年愛媛県全体及び松山市近郊の 一農山村地域において、女性の貧血 が增加傾向にある。そこで我々は、 前期 (1984-90 年)及び後期(1991-95 年)に 当地域住民を対象に、健康調査とフード モデルを用いた 3 日間の聞き取り栄養調 查を実施した。今回はその前期、後期とも に調查が実施できた女性63名を分析の対象

として、貧血と食生活（後期の栄養調 查の結果）との関連性について検討 した。また朝、昼、夕食別の鉄摃取量を元 に、 3 食別の鉄摄取量の割合を算定した。

\section{1. 貧血者の状況}

貧血者は 40 歳代までが特に多く、平均 $\mathrm{Hb}$ 值も低い。また 5 年前の $\mathrm{Hb}$ 值と比較 すると、30 歳代に低下傾向が認めら れた。また全体の变化では 6 人は貧血 のまま変化がなく、21人は $\mathrm{Hb}$ 值が低下し、 逆に上昇した人は 13 人のみであった。した がって女性の約半数は貧血にいつでもなる 可能性があることが示唆された。

\section{2. 貣血と食生活の実態}

今回の $\mathrm{Hb}$ 濃度を貧血（ $\mathrm{Hb}=12.0$ 未満）、 境界 $(\mathrm{Hb}=12.0$ 以上）、正常（Hb=13.0 以 上)の 3 群に分け、各種の栄養素充足率 $90 \%$ 未満の人の割合を比較した。貧血群にはエ ネルギー、蛋白質及び鉄の不足している人 が他の群と比較して多く認められた。
魚の摄取頻度週 4 日以上の人は正常群と 比較して貧血群に少なく、肉の摄取頻度週 4 日以上の人は境界群に少なかった。また、 卵と牛乳の攝取頻度週 6 日以上の人は貧血 群及び境界群に少なかった。

食品群別摂取量では、肉、乳製品、大豆 製品、有色野菜及び海草の摂取量が正常群 と比較して貧血及び境界群に少なかった。

次に、食品群別の鉄撕取量を検討した。 大豆製品及び海草からの鉄摄取量は、正常 群と比較して貧血群及び境界群に少なかっ た。魚からの鉄摃取量は境界群に少なかっ た。一方、有色野菜掑取量は貧血群よりも 境界群が少なかったにもかかわらず、有色 野菜からの鉄摂取量は貧血群が他の 2 群よ りも少なかった。

鉄の摃取量の 3 食配分の状況については、 正常群は朝食で 1 日の鉄摄取量の内の $25 \%$ 以上を摄取している人が多く、一方、貧血 群では夕食で 1 日の鉄撕取量の内の $40 \%$ 以 上を摃取している人が多かった。

3. 貧血と食生活改善の取り組み

後期の栄養調査の時に、「5 年前の栄養 調查の後食生活改善に取り組みました か?」と尋ねたところ、「食生活改善の取 り組みが続かなかった」と答えた人が貧血 群に多かった。 
2G14 血管肉腫における $\gamma \mathrm{I} L-2$ についての薬剤師の評価

$$
\begin{aligned}
& \text { 畔柳, 敏你, 米山 英二, 斎竹 達郎 } \\
& \text { 戸澤 良夫, 水谷 勝, 内田 雅之之 } \\
& \text { ( J A 愛知厚生連 更生病院 薬剂科, 皮膚科*) }
\end{aligned}
$$

血管肉腫 $\quad \gamma$ I L -2

\section{＜はじめに >}

血管肉腫とは、一般的に悪性血管内皮細胞 腫をさし、頭部から顔面にかけて多発する。 発生頻度は、皮膚や軟部組織の悪性間葉系腫 瘍全体の $1 \%$ 以下とされる極めて稀な疾患で ある。予後も極めて不良で、一年から数年で 死亡する例が多く、初診日から死亡までの平 均生存期間は 13.0 ケ月という報告もある。 症例が稀であり、また $\gamma$ I L - 2 が高価な薬 剂であるため、投与方法を含め薬剤科でフォ ローしてきた。今回、その経過について医師 と協力して薬剤師として評価してみた。

$<$ 症例 $>$

\section{5 歳 女性}

血管肉腫は頭部を中心にあらわれ、合併症 としては胃潰瘍、骨粗鬆症、癌性疼痛などが ある。初診は平成 5 年 7 月 9 日で第一回入院 時（平成 5 年 7 月 22 日）より電子線照射と $\gamma$ I L - 2 の投与を開始した。その後経過良 好のため退院し、外来にて週に $1 \sim 3$ 回の $\gamma$ I L -2 の投与を続ける。ところが、平成 8 年 5 月に左後頸部、9 月に頭頂部に新たな潰 瘍が出現した。血管肉腫の再発と考え、電子 線照射と $\gamma$ I L - 2 の静注、局注を繰り返す が、潰瘍局面は徐々に拡大した。そこで $\gamma \mathrm{I}$ L-2 の動脈注入を試みた。

\section{$<$ 方法>}

平成 9 年 1 月 15 日より再度入院した。血

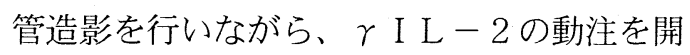
始した。
$\begin{array}{llr}R p ） \text { 動注 } & \text { 生 食 } & 5 \mathrm{~m} \mathrm{l} \\ & \gamma \mathrm{I} \mathrm{L}-2 & 40 \text { 単位 }\end{array}$

同時に手術により外頸動脈にテフロンチュー ブを留置した。さらにペインコントロールを 行った。

<結果>

腫瘍範囲は減少し隆起もなくなる。また、 拡大傾向もなくなり経過は良好である。5月 2 日にテフロンチューブを抜去し $\gamma$ I L -2 の投与を中止した。

<考察〉

血管肉腫にもかかわらず、平成 5 年より約 5 年という長期間の延命効果を示したことに

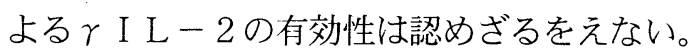
また、局注、静注の他に動注も有効な投与方 法と考える。さらに、一般的な副作用として 発熱等の全身症状が考えられるが、幸いにも 問題となる症状は見られなかった。肝臟、腎 臓に対する慢性毒性も現れず、好酸球への影 響及び貧血もみら机かった。これらにより、 $\gamma \mathrm{I} L-2$ は血管肉腫に対して安全かつ長期 間投与の可能な薬剤であると考えられる。

\section{<参考文献 $>$}

化学療法の領域 94 , v O 110 , No 6 $\mathrm{Sk}$ in Cance r Vol 1 , No 2 皮膚臨床 $26: 1395-1398,1984$ 臨皮 $39: 401-405,1985$ 
2G15皮膚 B 細胞性リンパ腫の 1 例

ב 南谷野妙子、百瀬文雄 ${ }^{1)}$ 、菊池正教 ${ }^{2)}$
(総合病院取手協同病院皮膚科、歯科口腔外科 ${ }^{1)}$ 、病理 $\left.{ }^{2)}\right)$

皮膚 B細胞性リンパ腫

\section{〈緒言〉}

皮庿に原発するリンパ腫の多くは T細胞性 であり、皮膚原発 $\mathrm{B}$ 細胞性リンパ腫の報告は比 較的少ない。今回我々は皮膚に原発した $\mathrm{B}$ 細胞 性リンパ腫を経験したのでここに報告する。

\section{〈症例〉}

患 者: 73 歳、女。

初診: 平成 9 年 2 月 24 日。

現病歴: 初診の 6 力月前より、右願部に自覚症 状を欠く発赤した腫瘤が出現。当院歯科口腔外 科にて抜歯および抗生剤の投与を受けるも改 善せず、当科を紹介された。

現 症: 右願部に径 $35 \mathrm{~mm}$ の境界不鮮明な弾性 軟の暗赤色腫瘤を認めた。所属リンパ節は触知 しなかった。

検查所見: 末梢血、臨床化学検査では異常なし。 Ga シンチ：右下顎に集積増強を認めた。

顎部 MRI : 䫟二腹筋より浅層に $34 \times 31 \times 17 \mathrm{~mm}$ の 限局性の腫瘍塊を認めた。

胸・腹部 CT : 異常なし。

病理組織検査：真皮全層にわたり、びまん性に 中型の異型リンパ球が稠密に浸潤し、一部では 胚中心を形成。核分裂像は少なく、異型性の程 度は軽度である。免疫組織染色では、L-26、 MB-1、Ig $\lambda$ 鎖、IgGに陽性を示した。以上より 自験例を皮膚 B 細胞性リンパ腫、diffuse medium-sized cell type と診断した。 経過 : 放射線療法を行った。6 MeV リニアック電 子線で計 $46 \mathrm{~Gy}$ 照射したところ、2 カ月後には腫 瘤は消退し、現在経過観察中である。

\section{〈考察〉}

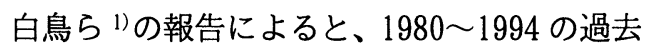
15 年間に、本邦では 77 例が皮膚 B 細胞性リン 腫として報告されている。それによると、男女 比に性差なく発症年齢の平均は 62.2 歳であっ た。臨床的には様々の大きさの腫瘤を呈し、単 発と多発の比はほぼ同数であった。病理組織学 的には diffuse large cell type が最も多い。 予後については、多発性病変では死亡率が $30 \%$ であるのに対し、単発性では $15 \%$ である。治療 法については、多発例では CHOP 等の化学療法 が施行されることが多く、単発例では放射線療 法を主体とし、化学療法や手術の併用も行われ る。

自験例は単発例であるものの、病理組織学的 には diffuse type であり早期から多臟器へ浸 潤する可能性があり、今後も慎重な観察が必要 であろう。

\section{〈文献〉}

1) 白鳥麻紀、菊池 新、松本博子、他. 皮膚 B 細胞性リンパ腫の治療. 臨皮 1996 ;50(9) :679683. 
$2 \mathrm{G} 16$ 和裁従事者にみられた㻴状肉芽腫の 1 例

矢島晴美

（秋田厚生連 山本組合総合病院・皮膚科）

和裁従事者、環状肉芽腫

〈緒言〉 環状肉芽腫の病因は未だ不明であ るが、その誘因となるものとしては外賃、虫 刺症、金療法、露光などが指摘されている。 また、特に汎発性環状肉芽睡では糖尿病との 関連も指摘されている。今回、和裁従事者の 右手背に発生し、和裁の作業による機械的刺 激との関連が疑われた環状肉芽腫の 1 例を報 告する。

<症例 >

患 者 52藏、女性、和裁従事者

初診 1997年4月14日

主 訴 右手背の皮疹

家族歴 特記すべきことなし。

既往歴 特記すべきことなし。結核、糖尿 病の既往なし。

現病歴 約 6 力月前より右手背に自覚症状 の無い皮疼が生じ、徐々に増大してきた。ま た、約 2 カ月前より、その近傍に同様の皮疹 が生じてきたため、当科受診となった。

現 症 右小指背MP関節部に一致して、淡 紅色、やや光沢を有する米粒大ないし小豆大 の硬い小結節が融合し、ほほ環状に配列しな からら示指頭大の局面を形成している。その約 $2 \mathrm{~cm}$ 離れた右手背には、米粒大および小豆大 の同様な小結節を 2 個認める。

鑑別診断 環状扁平苔癕、手白痽、持久性 隆起性紅斑、皮膚サルコイドーシス、 annular elastolytic giant cell granuloma 病理組織学的所見 右小指背MP関節部の皮
疹から生検を行った。また、右手背の 2 個の 小結節は生検を兼ねて切除した。いずれも、 真皮上層から中層にかけて肉芽腫性病変があ り、リンパ球、組織球、類上皮細胞の浸潤を 認める。ラングハンス巨細胞の浸潤、乾酪壊 死は認められない。

以上の臨床像ならびに病理組織学的所見よ り、環状肉芽腫と診断した。

治療および経過 ステロイド外用にて経過 観察中であるが、やや縮小傾向が認められ

る。

〈考按〉環状肉芽腫の病因は不明である か、虫刺症や薬剤使用との関連、また、本症 が露出部に多いことから外傷や日光との関係 を重視する者もある。さらに、最近の免疫学 的進歩に伴い、細胞性免疫および夜性免疫の 関与も考えられている。患者は約30年間和裁 の仕事に従事しており、初発した右小指背MP 関節部は常に機械的刺激が加わる部位である ため、自験例においてはその刺激が誘因と なった可能性が大きいと思われた。 
2G17 肉芽腫性および線維性エプーリスにおけるテネイシンおよび血液凝 固姻因子陽性細胞の分布に関する免疫組織化学的研究

\section{渡辺三三雄、土井田誠、井上晋吾、中村知美、内藤 斉* 松原功典*}

(揖斐総合病院、歯科口腔外科、中央検査科*)

エプーリス、テネイシン、血液凝固姐因子

く緒言〉テネイシンは胎生期の幼若な結合組 織や癌の間質のみならず肉芽形成や組織修復 などにおいて早期に広く発現することが知ら れている。また血液凝固㚼因子 (以後 F X لlla) はフィブリン相互のみならずフィブロネクチ ン相互、間質型コラーゲン相互あるいはフィ ブロネクチンと間質型コラーゲン間の架橋結 合を促進することが知られていることから、 結合組織形成や線維化の過程において重要な 役割を演じていると考えられている。今回わ れわ机は肉芽腫性および線維性エプーリスに おけるテネイシンと F X Xلla陽性細胞の分布につ いて免疫組織染色をおこなった。

<方法>肉芽腫性打よび線維性エプーリス56 例について、ベクター社製ベクタステインA BCキットを用いて免疫染色を行なった。一 次抗体としてはケミコン社製、抗ヒトテネイ シンウサギポリクロナール抗体とセルビオ社 製、抗ヒト F 期ウサギポリクロナール抗体を 使用した。発色にはD A B を、核染色にはメ チルグリーンを用いた。

（結果＞肉芽腫性エプーリスでは上皮および 血管内皮の基底膜相当部から間質に向かって 樹枝状ないし細線維状に広がるようなテネイ シン強陽性像が認められ、上皮下の肉芽組織 内には星芒状を呈する大型の F 相陽性細胞が 多数認められたが、 $\mathrm{F}$ 刴陽性細胞の分布に一 致して周囲の基質中にテネイシンの発現が認 められるわけではなかった。線維性エプーリ スにおいては、テネイシン強陽性所見は一部
の血管基底膜に認められるのみで、上皮の基 底膜には不連続の弱い陽性像が認められるに すぎず、上皮下の線維性結合組織内には主に 紡錘形を呈する F 亚陽性細胞が少数認められ るにすぎなかった。

〈考察〉肉芽腫性エプーリスから線維性エプー リスに変化する過程において F Xل1川陽性細胞と テネイシンの分布は必ずしも重なるわけでは なかったが、両者の分布には一定の関連性が 認められた。なお $\mathrm{F}$ X相陽性細胞はマクロファー ジ／組織球系の細胞とする説が有力であるが、 われわれが先に観察したマクロファージの分 布・形態と F 期陽性細胞の分布・形態とは良 く一致しており、F 則陽性細胞はマクロファー ジ／組織球系の細胞であることが強く示唆さ れた。

（結論＞1）肉芽腫性エプーリスにおいては 上皮の基底膜にテネイシン強陽性像がみられ、 上皮下の肉芽組織内に星芒状で大型の F X $\mathrm{d}$ 陽 性細胞が多数認められた。しかし、必ずしも 両者の分布は重ならなかった。2) 線維性工 プーリスにおいては、上皮の基底膜に不連続 のテネイシン弱陽性像がみられずにすぎず、 上皮下の線維性結合組織内には主に紡錘形を 呈する F 泟陽性細胞が少数認められるにすぎ なかった。3） F 泟陽性細胞はマクロファー ジ/組織球系の細胞であると思われた。 
出口喜昭、山口浩、安藤純一、丸山博志、吉井昭夫、

橘田輝雄、高橋唯朗

一 伊势原協同病院 -

心房細動 脳塞栓 統計調查

鍺言 心房細動は頻度の高い不整脈の一つ

である。眽拍の異常より容易に診断され心電 図記録により確定するが、無自覚・無症状で 治療を必要としないものがある反面、最大の 合併症である脳血栓塞栓症を引き起こすこと がある。今回我々は当院に㧍计る過去三年間 の心房細動の患者とその合併症である脳塞栓 症との関係について統計学的調査を施行し検 討したので報告する。

対象および方法対象は平成6年4月よ り8年3月までの3年間に伊勢原協同病院に入 院あるいは外来受診し、12誘導心電図で心 房細動（以下Ａ） と診断し得た症例、379 例（男230女150）及び頭部C T、臨床症状 から脸塞栓症 (以下CI) と診断され入院となっ た160人。

結果 当院にお打るA f の患者は379人で 男女年嚙別にみると男性は60瓷代，女性は 80歳代で最も多かった。更にこれらの症例 の基磉疾患について見てみると、高血圧、狭 心症等の非弁膜性心疾患が $62 \%$ と最も多く、 次いで基礎心疾患を有さない 1 。 n e Afは 22\%であった。またこれら 379 人の内 1 65 人 (44\%) がワーファリン、アスビリ ン、チクロビジン等の抗疑固療法が施行され ていた。同時期の3年間に当院で発症した C I 患者は160人でその中の16人（10\%）に Afが認められた。16人の詳細について見 てみると発症前より抗凝固をおこなっていた のは1例あったが、この1例も発症一週間前
より内服がなされていなかった。また死亡を 含めた重症例は6例見られた。lone Afl4例 で全例が機能障害を残さない軽症例であった。 年䞮での重症度分類では軽症例、重症例と有 意差を認めなかった。

考察 当院は神奈川西南部にあり。その地 域的特徴として 比較的高齢者が多く、また 現在の社会的状況をみてもますます高路化が 進むと思われる。A f に関する大規模試駼は 米国をはしめ各国で施行されつつある。その 中では65才を越えると心房細動の有病率は 增加し、その中央值は75才で、これは当院 でも同様の傾向が見られた。A f で I の合 併率は、年柃の增加とともに上昇すると言わ れているが、今回の調查では年皊の增加と C Iの合併率で有意差は見られなかった。抗 凝固療法については、大規模試験で行われて いるような薬品別の检討ができなかったが、 当院では約半数の患者が抗凝固療法を行って いた。さらに内服中のC I 合併例は 1 例のみ であった。その 1 例も、チクロビジン服用休 止 7 日後にCI が発症した事から考えて、年 䊀に関倸なく基礎心疾患を合併したA f 症例 ては、何らかの抗疑固療法を行ってCIの予 防を行っていくべきであると考える。

結論過去 3 年間の心房細動患者につい て統計調查を行い、基礎心疾患を有する心层 細動患者では、脳塞栓の合併予防のために抗 凝固療法を行うことが必要と思われる。 
2G19 虚血性心疾患におけるR L P - Cと総コレステロール, トリグリセライドとの監床的感度の差

下浜 孝郎 - 山口浩 ·出口 喜昭 - 吉井 昭夫

滳田 輝雄 - 高橋 唯朗 - 伊藤 健二 · 米山桂八

R L P - C, L P ( a ), 冠危険因子, 動脈硬化

＜諸言＞最近，高トリグリセライド血㱏が動 鲧硬化の危険因子として再評佰されている. 我々は, トリグリセライドの主体である T G リッチリポ蛋白の中間代謝産物であるレムナ ント・リポ蛋白ーコレステロール (RLP-C)值 を瞾し，従来より言われている危険因子と の優位性を検討したので報告する.

く方法>対象は, 当院にて虚血性心疾患を疑 われ心灌カテーテル検査を受けた患者 30 名. 冠動係の狭窄の程度により正常対照群( 以下 C群, $n=10$ ), 1 枝病变群（以下 । 群, $n=6$ ), 2 枝病変群 (以下 II 群, $n=7$ ), 3 枝病変群（以下 III群, $n=7$ ）に分け，12時間以上絶食した状態 で採血し，粉コレステロール（以下TC）值, トリグリセライド（以下TG）值, HDL-C值, RLP

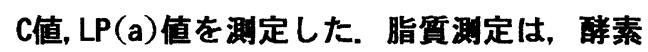
法による自動分析法で, HDL-C值はデキストラ ン硫酸 C a 沈降法で測定 LP(a)值は,Biopool 社のキットを用いたELISA 法により, RLP-C值 は日本抗体研究所のJIMRO- IIを用いた.

<結果>TC值は, C群 185.5 $1837.9 \mathrm{mg} / \mathrm{dl}$, I 群 218. $2 \pm 47.7 \mathrm{mg} / \mathrm{dl}$, II 群 $226.2 \pm 55 \mathrm{mg} / \mathrm{dl}$, III

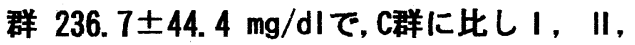
III群とも有意に高く、 III群が最も高值であっ た. TG值は,C群 $130.6 \pm 43.5 \mathrm{mg} / \mathrm{dl}$, I 群 145 $\pm 55.0 \mathrm{mg} / \mathrm{dl}$, II 群 $132.2 \pm 50.7 \mathrm{mg} / \mathrm{dl}$, III群 12 $7 \mathrm{mg} / \mathrm{dl}$ で平均值において। 群が最も高值を示 したか，群との明らかな有意差は認めなかっ

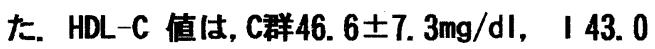

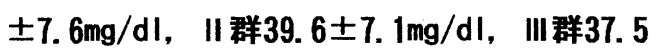
士4. $4 \mathrm{mg} / \mathrm{d}$ 『であった. 平均值では, C群に比し I群は低值であったが有意差は認めなかった ． II， III群は,C群に対して有意に低值であっ た.LP(a)值は, C群17. 3土15. 0mg/dl, I 群21. 3 $\pm 9.07 \mathrm{mg} / \mathrm{dl}$, II 群30. $20 \pm 14.57 \mathrm{mg} / \mathrm{dl}$, III群 21. $25 \pm 9.29 \mathrm{mg} / \mathrm{dl}$ であり平均值において । , II, III群は C群より高值であったが, ばら つきが大きく有意差は認めにくかった. RLP-C 值は, C群5. 04士2. $45 \mathrm{mg} / \mathrm{dl}$ ， I 群7. $97 \pm 3.80 \mathrm{mg}$ $/ \mathrm{dl}$, II群7. $40 \pm 3.83 \mathrm{mg} / \mathrm{dl}$, III群7. $32 \pm 3.36 \mathrm{mg}$ /dl であった.LP-(a) 同様平均值において I , II, III群は,C群より高值を示したが有意差 は認めなかった.

〈考察>RLP-C 值は，その平均值において対 照群より冠動睬有意狭䂟群の方が高值を示し たが, T-CHOやTGの様な有意差は認めにくかっ た. 冠動係有意狭窄群をさらに心箭梗塞群と 狭心症群に分類し，検討して見る必要がある と思われた.

<結諭〉

T-CHO 值, HDL-C 值は, 冠動胉硬化と有意な 相関関係を認め, 血中濃度依存的であった. TG值は, 冠動膘硬化と有意な相関関係は認め なかった. LP (a) 值は, 平均值において対照 群より冠動鲧硬化群のほうか，高值であった が、゙らつきが大きく有意差は認めにくかっ た. RLP-C 值む, 平均值において対照群より 冠動係硬化群の方が高值であったが，やはり 有意差は認めなかった。 


\section{G20 当院における肺アスペルギローマの治療経験}

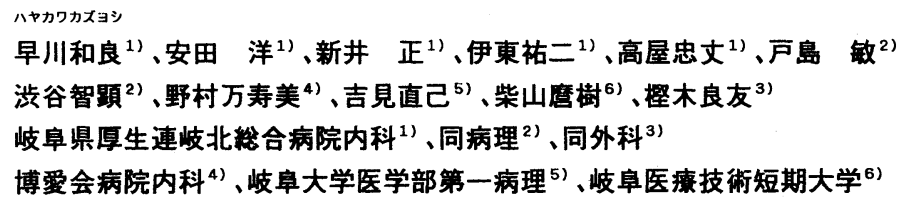

\section{肺アスペルギローマ抗真菌剤空洞内注入療法}

はじめに

いわゆる菌球型肺アスペルギローマは、他の真 菌症と同様に宿主の抵抗力の低下を来す基礎疾患 において合併例を散見する。今回我々は、最近経 験した同症 5 症例を検討し、診断と治療経過につ いて報告する。

症例 $1: 71$ 歳男性、 6 年前に肺結核の既往あり。 自覚症状なく近医の定期検診の胸部 $\mathrm{X}$ 線写真にて 異常を指摘され、当院来院。CT 上左中肺野に空洞 を伴う腫瘤を認め、気管支鏡による TBLBにてア スペルギルスの菌糸を確認した。抗真菌刘の経口、 経静脈的投与を施行し、菌球の縮小を確認したが、 その後他院に転院となった。

症例 $2: 62$ 歳男性、30 年前に肺結核の既往あり。 咳濑時に血痰と喀血を自覚し来院。胸部 $\mathrm{X}$ 線、CT 上左肺尖部に空気層を伴う腫瘤陰影を確認、同部 のTBLBにて同症之診断した。抗真菌剤の経静脈 的投与を施行したが著変を認めず、経気管支的に 数回投与を施行したが、大腸癌の合併により死亡 した。

症例 $3: 40$ 歳女性、 7 年前に肺結核の既往あり。 当院通院中、胸部 $\mathrm{X}$ 写真上右肺尖部の空洞内に腫 瘤影が拡大し、CT 上空洞内に可動性のある菌塊陰 影を確認。菌糸は確認できなかったが抗体陽性で 同症と診断し、外科的に区域切除を施行され、根 治した。

症例 $4: 71$ 歳男性、 3 年前に肺結核の既往あり。 当院通院中、定期の胸部 X 線写真上左肺尖部に陳 旧性陰影の増強を指摘され、CT 上空洞内に充満す る腫瘤影を確認、TBLBにて同症之診断。経気管 支的投与と内服にて経過観察中、手術を勧めてい る。

症例 $5: 83$ 歳男性、結核の既往不明。15 年前に 喀血歴あり。咳濑之共に喀血し来院。胸部 $\mathrm{X}$ 線写 真上左肺尖部に巨大な腫瘤影を認め、 CT 上空洞壁 より内腔に突出する結節影を確認。気管支鏡では 上区に気管支内腫瘤を確認し生検で同症之診断。 経皮的に空洞内にチューブを留置し抗真菌剤を連 日注入した。陰影の改善と症状の軽快を認めたが、 2 年後全身衰弱にて死亡した。

\section{考察}

肺アスペルギローマは宿主の抵抗力の低下を来 す疾患に合併が多く、特に空洞を有する結核では フォローアップに注意を要する。我々の症例でも 5 例中 4 例が結核に合併している。症例 5 は結核 の既往は明らかでないが、気管支鏡にて菌塊が気 管支を閉塞していたことから、何らかの check valve 的な作用の関与も考えられる。診断にはア スペルギルス抗体陽性が参考になるが、決め手は 喀痰やTBLBでの細胞診や組織所見で菌系を確認 する事である。治療においては、外科的切除が最 も根治性に優れ有効とされているが、患者の多く が高秢で低肺機能や全身状態の不良を合併してお り、その適応とならない事が少なくない。内科的 治療亡して抗真菌剤の経口、経静脈的、経気管支 的、経皮的投与、吸入療法がある。経口や経静脈 的投与は空洞内に十分な濃度で移行しないため効 果は薄く、最近では気管支鏡を用いた経気管支的 投与が多く行われている。しかしこの方法もその 都度気管支鏡を施行せねばならず、また根治性も 期待できない。経皮的空洞内注入療法は、最近報 告が散見される方法であるが、部位的に穿刺が可 能であれば有効な手段と思われる。我々は症例 5 において本方法を試みた。本例では胸壁に接して 空洞が存在したため、比較的安全にチューブが空 洞内に留置できた。薬剤の使用量、回数等の検討 は未だなされていないため、独自で 1 回 $30 \mathrm{mg}$ と 設定し連日投与とした。 5 力月間で計 97 回、総量 2860mg のミコナゾールを投与し、有効な縮小効 果を得た。しかしどの内科的治療でも根治には至 らないのが現状で、我々の症例においても治癒し たと言えるのは外科的治療をし得た症例 3 のみで あった。外科的切除が選択できない場合の、より 有効な内科的治療法の検討が待たれる。

参考文献

1.藤本欣也、他 : ミコナゾールの経皮的空洞内注 入療法が著効した肺アスペルギローマの 1 例. 日 胸 1991;50(1):82-7

2. 早川和良, 他 : 抗真菌剤の空洞内注入療法が有 効であった肺アスペルギローマの 1 症例。気管支 学 1996,18(2)133-139 


\section{G21 せん妄患者91例（平成8年）に関する精神医学的検討}

シンノヒデト

\section{新野 秀人}

\section{広島県厚生連広島総合病院精神科神経科}

せん妄、ハロペリドール

く緒言〉せん妄は種々の身体疾香や脳器㰓疾 患を誘因として生じ、軽度の意識障害を基礎 として特幑的な病像がみられる。急激に発症 し浮動することが多く、注意の集中や持続が 低下し、記憶障害や見当識障害など認知能力 の変化が認められる。睡眠・覚醒リズムが障 害され、夜間に多動や徘䧃などをおこすがあ とで覚えていない。他診癔科で入院治癔中に 例を対象として、せん妄の経過・治療・增覀 因子などについて検討した。

<方法と対象>対象：平成8年1月から同年 12月の1年間に広岛県厚生連広島総合病院精 神科神経科を受診した患者のなかでせん妄と 診断された91例（男性42例、女性49例）。 平均年龄78.4 8 8.5藏。薬物癔法：ハロペリ ドール（HPD）を第一選択薬として使用し た。HPDが無効の場合には症例に応じて併 用薬を選択した。研究方法 : 治癔後のせん妄 の転帰、有効薬剤、治療開始までの期間と宽 解までに要した日数の相関、そしてせん妄が 遷延した症例ではその要因を検討した。

〈結果〉(1)せん妄の転帰：91例のうち72例 が軽快(軽快群)、12例が一旦軽快した後に再 然(再燃群)、4例が不変・变動(不变群)、3例が 中断した。軽快した72例のうち58\%が治療 後2日以内に、79\%が4日以内に軽快した。 軽快群のなかでも5日以上を要した症例や再 燃群、不変群では低酸素血症、腎機能障害、

た。(2)治癔開始までの期間とせん妄軽快の所 要日数：せん安が出現から治療開始までが7 日末満だった症例ではせん妄が軽快するまで に平均1.8土1.1日要した。これに対して治療 開始までに7日以上を経過してした症例では 平均6.6士5.2日要した。(3)有効薬剤: 軽快群 +再燃群の84例のうち78例でHPDが有効だ った。そのうち 15例では経口摂取ができず 注射を施行した。HPD内服薬の有効量は0.5$4.0 \mathrm{mg} /$ 日で平均 $1.4 \pm 0.9 \mathrm{mg} /$ 日だった。 その他にチアプリド単独で2例、HPD+ミア ンセリンで2例、HPD+カルバマゼピン、 $\mathrm{HPD}+$ クロナゼパムで各1例が軽快した。 〈考察〉全対象のうち $92 \%$ 症例でせん妄 が軽快した（軽快群十再燃群）。多くの場合 HPDが有効だったが、効果が不十分な場合 には症例によってミアンセリン、カルバマゼ ピン、クロナゼパムなどを選択して併用した。 HPDの効果がそしい症例では低酸素血症な ど脳代謝に悪影䈏を及ぼす要因が認められ、 しかも基礎疾患の諸症状が遷延することでせ ん妄も遷延することが多かった。また、せん 妄を生じてから治療を開始するまでの期閫が 1週間以上の群ではせん妄が軽快するまでの 所要日数が有意に長かった。

<結論〉早期から認知力低下や睡眠・覚醒り ズム障害などの症候を把握し、環境調整や HPDを主体とした薬物療法を行う必要があ る。また、誘因となる基礎疾患の諸症状が遷 延することでせん妄も遷延することも多い。 


\section{G22 小刻み歩行を呈する多発性脳梗塞患者におけるMRI画像上の脳梁断面積の検討 \\ ヌノムラシンイチ \\ 布村仁一、前田哲也、小山慶信、西江信 \\ (由利組合総合病院・神経内科)}

\section{多発性脳梗塞、脳梁、小刻み歩行}

【目的】多発性脳梗塞を呈する患者では歩行 障害、特にいわゆる小刻み歩行を示す場合が ある。この症候は前頭葉白質病変との関連が 指摘されてるが定量的に評価した報告は少な い。脳梁は左右大脳半球をつなぐ重要な神経 回路であるが、大脳白質の構成成分としても 重要でその大きさの計測は白質に及ぼす疾病 の影響を評価する上で有用と思われる。今回 我々は多発性脳梗塞患者における小刻み歩行 発症に対する大脳白質病変の関与の有無 と主 たる責任病巣を明らかにする目的にMRI上の 脳梁断面積について検討した。

【対象】対象は小刻み歩行を呈しMRIにて確 認された多発性脳梗塞患者(小刻み歩行(+)群)6 例(全例男性 : 平均年齢70.2歳,平均䍜病期間 6.4年)。対照として小刻み歩行を呈さない多 発性脳梗塞患者(小刻み歩行(-)群)10例(男 4,女 6 : 平均年齢70.3 歳)及び正常対照者(正常 群)10例(男3,女7 : 平均年齢68.3歳)を用いた。

【方法】MRIT1強調正中矢状断面画像をApple 社製コンピュータに取り込み画像処理ソフト NIH imageにて脳梁断面積を計算した。また脳 梁断面積の脳の大きさの個人差によるばらつ きを補正する目的で、同じ断面における頭蓋 内腔断面積を同時に計測し、脳梁断面積 /頭 蓋内腔断面積比 $(\mathrm{CC} / \mathrm{IC}$ 比)を計算し、相対值と して検討した。また脳梁は前部、幹部、膨大 部の3領域に分割してそれぞれの断面積も同様 に計測し検討した。

【結果】脳梁全体のCC/IC比は小刻み歩行 $(+)$
群で $0.036 \pm 0.003$ と小刻み歩行(-)群( $0.045 \pm$ $0.007) 、$ 正常群 $(0.048 \pm 0.007)$ の゙ちらに対 しても有意に低下していた $(\mathrm{p}<0.01)$ 。脳梁部 位ごとの比較では、前部では小刻み歩行(+)群 は(-)群、正常群と比べCC/IC比は有意に低下 していた $(\mathrm{p}<0.05)$ 。幹部では CC/IC比は小刻み 歩行(+)群は正常群と比べ有意に低下していた が(p<0.01)、(-)群とは有意な差を認めなかっ た。膨大部では小刻み歩行(+)群は(-)群、正常 群のどちらに対してもCC/IC 比の有意な低下 を認めた。

【考察】今回の我々の検討では。小刻み歩行(+) 群は脳梁全体としての萎縮が認められ、小刻 み歩行発症に対する白質病変の関与が推定さ れる。また脳梁内を通る交連線維の投射先は 脳梁の部位によりおおまかに推定され、今回 の結果からは主に前頭葉よりの線維を含む前 部は小刻み歩行(+)群で有意に小さく、以前よ り指摘されている多発性脳梗塞患者の歩行障 害に対する前頭葉病変の関与を支持する結果 といえる。また膨大部でも有意な萎縮を認め たが、一般に膨大部は加齢に伴う生理的変化 が少ない部位とされており、小刻み歩行発症 に対する関与が注目される。一方幹部は有意 な差を認めず、頭頂葉、側頭葉の関与が比較 的少ないことが想定された。

【結語】小刻み歩行を呈する多発性脳梗塞患 者では前部、膨大部主体の脳梁萎縮が存在し、 その責任病巣として前頭葉のみならずさらに 広範囲な白質障害の関与を示唆する。 


\title{
$2 \mathrm{G} 23$ 取手方式教育入院プログラムの作成 看護計画の開示にむけて
}

\author{
谷津京子、関田洋子、冨田絹江、有安百合子、 \\ 小林純子、塚本千恵子 \\ （総合病院取手協同病院 看護科）
}

取手方式

看護計画開示

\section{《はじめに》}

当院では腎不全保存期にある患者に対し、食 事療法による「教育入院」を実施している。そ の中で、入院すれば何とかなるだろうという依 存的な患者も少なくない。

そこで、何故依存的なのか、問題はどこにあ るのか患者自身に入院目的を明確にさせ、それ に基づいた看護計画を作成して開示し自分の 現状を認識してもらう事が必要と考えた。

\section{《研究方法及び研究対象》}

期間：平成 9 年 1 月 6 日 4 月 30 日

対象：低蛋白・高カロリー食を目的とした教育 入院患者 12 名

方法：(1)入院時に病識チェックプリントを記入 してもらう(2)自己管理ノート・血圧計・計量計 を渡し使用方法を説明する(3)受持ち看護婦が 病識チェックプリントに基づき、患者とともに 看護計画 (看護問題・看護目標・教育プラン) を立案し開示する(4)評価は 1 週間後患者ととも に修正・追加を行う。

\section{《結果・考察》}

(1)病識チェックプリントから検査データ・内 服薬·病識について $84 \%$ の患者が理解できてい ないことが判明した。そこで、あらかじめチェ ックプリントで個々の患者のウィークポイン トが絞られているので、患者にも看護計画を開 示しそこから説明を開始する（開示できたのは 16\%）。検査データを知らない患者はレベルの 差はあるが、たいてい腎不全についても知識不 足であることが判った。同じく内服薬について

も同様のことがいえるので結局「腎不全とは」 から説明していくことになり、検査データの見 方・内服薬の必要性を関連付けた説明ができる ようになった。

(2)自己管理ノートの導入については、(1)に挙 げたとおりそれぞれの必要性を説明した上で 毎朝の体重·3 回/Day の血圧測定・内服薬の 薬効などを記入してもらった。さらに食事に関 しては献立を計量計で測りノートに記入して もらった。ただ食事を体験すればよいというだ けで入院される患者が多かったのだが、「食事 を目で見て確かめられるようになった」「自分 でも作らなくては行けないと思った（男性）」 「日頃の生活にも注意できるようになった」な ど自らが病気をさらに身近なものとしてとら え、どう関わっていくか意識が持てるようにな った。患者に病状を認識させるには患者自身に 入院目的を明らかにさせることが必要である。 さらにそのことから看護の問題点が明確にな り、個々に合わせた指導も可能となる。

\section{《おわりに》}

今後も看護サイドの一方的な指導ではなく 患者とともに看護問題を共有し解決できるよ う、患者のニーズに添った看護が展開できるよ う看護計画の開示を定着させていきたい。な お、患者同士の交流の場としてコミュニティル 一ムの設置を検討中である。 
2G24 ベット上での足浴ケアの工夫〜足浴器を作成して〜

7ジ井扛

藤崎祐子、飯村由美子、染名喜代子、赤上優子、川又光子

（総合病院土浦協同病院 循環器内科病棟）

足浴器作成、入浴体験、労力軽減

はじめに 床上安静で入浴不可能な患者の足 浴は、患者の清潔への援助として看護の重要 な役割の一つになっている。しかし、現状で は十分な足の保温効果や入浴感覚が期待でき るまでには至っていない。また、看護婦から みた場合です、現在用いているプラスチック 製のベースンでは不便な点が多くある。そこ で今回、足浴時の保温性の向上と入浴感覚の 体験、および看護婦の労力軽減を目的に新型 足浴器の考察に取り組んだ。

I 、方法 従来の足浴器での問題抽出を行い 新型足浴器を作成した（図 1 参照)。そして 作成後の評価を行った。

II、結果及び考察 従来のプラスチック製の ベースンでは浅くて小さく安定感が覀いため、 寝具を污染してしまうことがあった。また、 湯量が少ないため十分な保温効果が得られず 図 1 〈操作手順〉

（1）精製水ヒニニールタンク（開閉コック付、

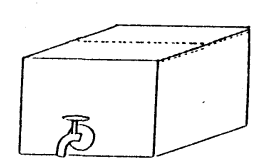

18 L) の上部をカット

（2）発砲スチロール (40 X $30 \mathrm{~cm})$ をカット

（1）を（2）に入れ、開䦥コックを穴から出す
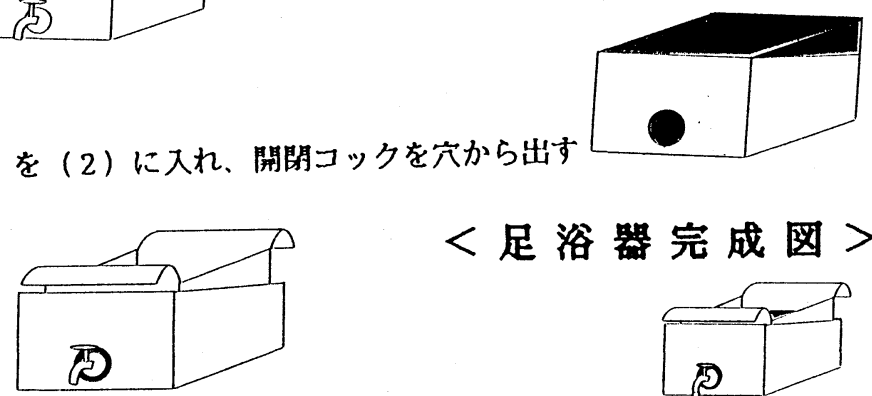

<足浴器完成図>

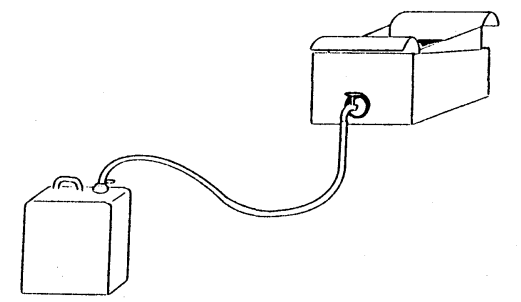

入浴感覚の体験もできていなかった。

そして、看護婦は湯の交換及び患者に対し て膝関節の屈曲位の保持に労力を要していた。 伊東、森田氏によると、効果的な足浴は、 室温19.0 23. $5^{\circ} \mathrm{C}$ で浴温 $40^{\circ} \mathrm{C}$ 、湯につかる時 間は 5 分間で、湯につかる部位は下腿 3 分の 2 の足浴が患者に負担をかけずに保温効果が 得られると報告されている。

今回考案した足浴器は、従来のあのよりあ 容器が大きいために下腿 2 分の 1 までお湯に つかることができ、足浴部位の拡大が得られ た。また、両足の同時足浴をしたことや発泡 スチロールを使用したことで保温効果が大き く、効果的な足浴に近づくことができた。

看護婦にとってす、新型足浴器は安定間が あり、ベット周囲の污染が少なく排水が可能 で、意識のない患者です足を屈曲した状態が 保持でき 1 人でも容易に行えるなど利点が多 くなった。このことから看護婦の労力軽隇に あつながると思われる。 以上より、新型足容器の 作成は患者のみならず看 護婦にとってあ有意義で あったと考える。

III、参考文献

1)第22回看護総合 1991年 120-123

2)看護技術 92-7 VOL38

No10 (1004-1008) 
$2 \mathrm{G} 25$ 早期頻回直接授乳が短乳頭裖婦に与える効果

ッボネアッコ

坪根敦子

（長野県厚生連北信総合病院・看護部）

裖婦、吸啜、直接授乳

【はじめに】日頃、扁平乳頭や陥没乳頭など、 直接授乳が困難な袪婦では、児が乳頭を吸っ てくれないことによる疲労を訴えることが多 い。そこで今回、短乳頭䘿婦に対し、分婏後 早期に頻回直接授乳を行い、その効果を調べ たので報告する。

【方法】平成8年7月から10月までに当院で経 腔分婏した短乳裖婦23名と、その新生児であ る。その内、早期頻回直接授乳群を対象群と し、分婏後 60 分時に1回と、分婏後 12 時間後 から3時間毎授乳を開始した。また、非早期 頻回直接授乳群を非対象群とし、直接授乳開 始は従来通り分婏後2日目からとした。そし てそれぞれ、産褛2日目と5日目に以下の3点 について測定し、wilcoxon検定を用いて比較 検討した。（1）母乳分泌量（2）乳頭吸啜率

（3）産業疲労研究所が提出した自覚症状調 査表を用いた疲労感の訴え率

【結果】（1）母乳分泌量については、両群 に明らかな差はなかった。

図1

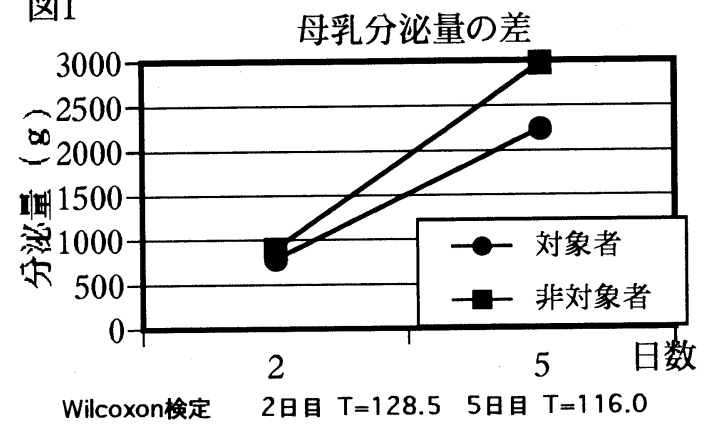

（2）乳頭吸啜率では、産裖5日目に対象群の 方が吸啜率が高いという結果を得た。

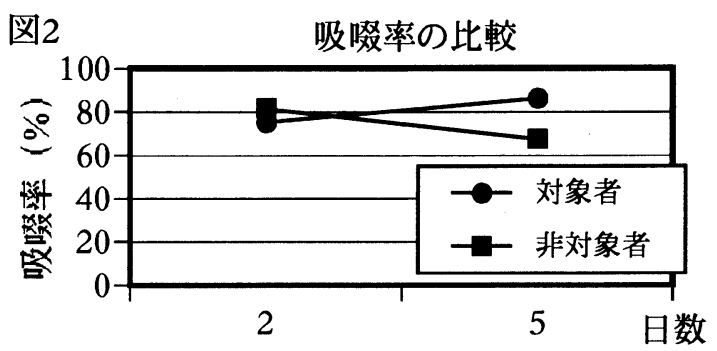

2日目 $T=114.00$ 5日目 $T=161.00$

（3）両群の疲労感の訴え率を表したものが、 図3、図4である。疲労感の訴え率では両群に 差はなかった。
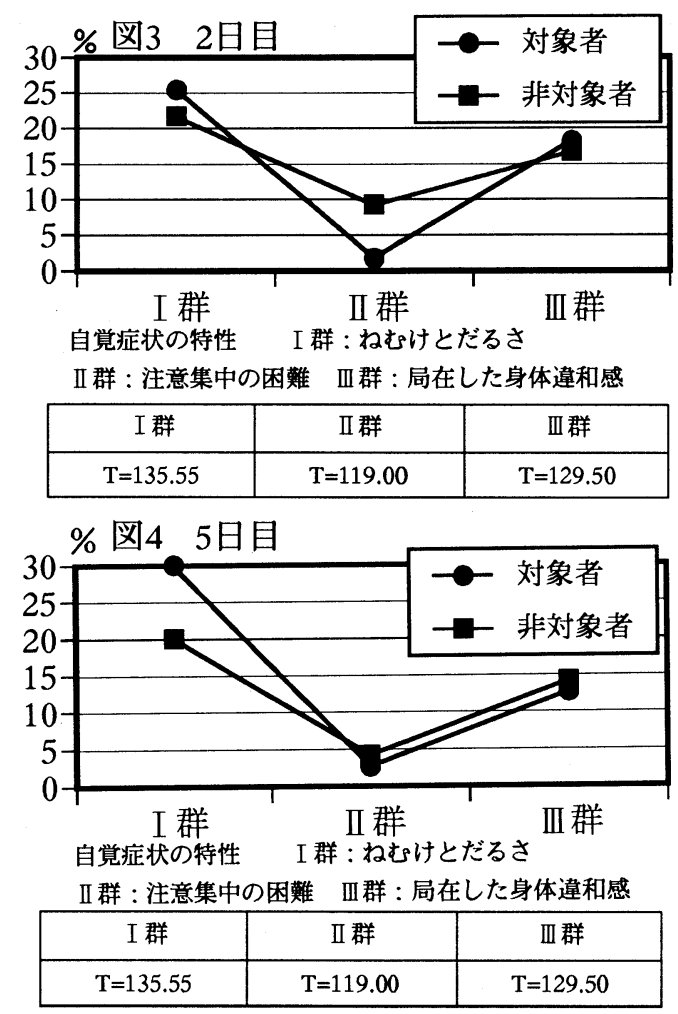

【結論】早期に直接授乳を開始することは、 短乳頭裮婦の乳頭吸啜率を上げる効果がある と言える。 


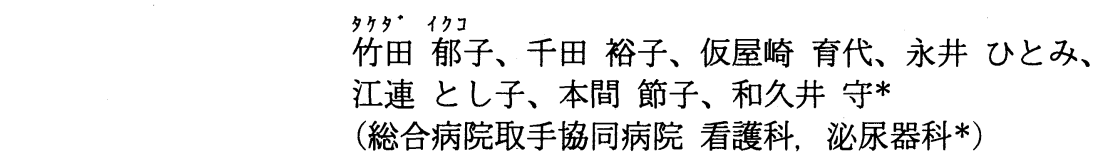

ストーマケア チェックリスト

【はじめに】回腸導管ストーマ（非禁制スト ーマ）は、パウチ（採尿袋）を貼ることを余儀 なくされる。そのため、個々にあったパウチを 決定しなくてはならないが、パウチを決定する までに、いろいろな要因で時間がかかり患者 に与える身体的・精神的苦痛が大きく、ストー マケアに対する看護婦の関わりが、重要視さ れる。

そこで、ストーマケアの統一性をはかり、患 者にあったパウチを選択するために、パウチ交 換時のチェックリストを作成し実施した。その 結果、患者の意見・要望が表出されるようにな り、看護婦一人一人の認識も高まり、以前より スムーズにパウチを決定できたと思われたの で、ここに報告する。

【対象】膀脱全摘十回腸導管造設術を受けた 男性患者 2 名 (64 歳· 71 歳)

【方法】パウチ交換を担当した看護婦が(1) ス トーマの状態、(2)皮膚の状態、(3)交換したパウ チ名、(4)何日目の交換かと交換理由、(5)パウチ 交換時の対処、(6)患者からの意見・反応、(7)看 護婦からの意見、8漏れの部位や発赤があれば その図、の 8 項目をチェックリストに記入し、 申し送った。

【結果及び考察】症例 $1 、 64$ 歳。ストーマ下 方に術後より小さな潰瘍があり、漏れの原因と なった。潰瘍部に創傷被覆材を使用、さらにパ ウチは患者の希望のコックつきを用いた。患者 は当初からストーマケアに対する受容が良く、 ケアに対しては意欲的であったため、患者が希
望するパウチを用いることにより、さらに積極 的に取り組むようになった。

症例 2、71 歳。ストーマ下方に虫垂切除創の 瘢痕があり、漏れの原因となった。瘏痕部にペ ーストで補強したが、患者は積極的な自己管理 には向かない性格で、ペーストを使用させるこ とは、難しかった。そこで、患者の性格を考虑 し、チェックリストを活用して、ペーストが不 要な凸面のパウチを選択した。その結果、以前 はストーマに対して受容はしていたが、ケアに 対する意欲がそしく、家族に依存していた患者 が簡単に貼れるパウチを使用することで、自己 管理が出来るようになった。適切な器材を選ん だことが患者の積極的な姿勢を引きだしたも のと思われる。

2 症例から得られた結果は、チェックリスト に記入し申し送ることでストーマケアの統一 化がはかれ、患者に適切なパウチの決定が速や かにできるようになったことである。また、患 者と看護婦の両者が同一の視点でストーマケ アをとらえることができるようになった。

退院後 2 名の患者はコスモスの会（院内スト 一マの会) でリーダーシップを発揮している。

【おわりに】 チェックリストを活用したこと で、ストーマケアの統一化がはかれ、患者に適 したパウチを選択できた。今後もチェックリス トを活用し、より良いストーマケアをしていき たい。 
$2 \mathrm{G} 27$ 心臓カテーテル検査のオリエンテーションの再検討

夘哗
田代真紀、浅香博子、大塚多美子、井上博美、
(総合病院取手協同病院 看謢科)

心臓カテーテル検查 患者の不安 オリエンテーション

\section{《はじめに》}

当科では、心藏カテーテル検査のオリエンテ ーション内容が統一されていなかった。 そのため、検査・治療に対する患者の質問や不 安の声が多く聞かれた。そこで、アンケート調 查を行い、パンフレットを作成して指導したこ とにより、検査への理解が深まり不安の軽減に つながったので報告する。

\section{《研究方法》}

対象者：CAG、PTCAを受ける入院患者 26 名 方 法：(1)アンケート調査

(2)新パンフレット作成

調査期間：改善前 H8.5 7月

改善後 H8. 8〜 10 月

\section{《結果および考察》}

アンケート調査の結果、看護婦からの説明は 分かりやすかったですかの設問に対し「良く分 かった」という回答が改善前 $50 \%$ から改善後 76. 9\%に増加した。この回答は、患者が医師の 説明を十分に理解できず、看護婦から専門用語 でなく、わかりやすい言葉で説明を受けた結果 の評価であり、新パンフレットを用いての説明 に効果があったことがうかがえる。検査につい ての不安は「ある」と回答した人が改善前 57.7\%、改善後 46.2\%であった。

また改善前には検查の方法や所要時間につい ての質問等がでたが、改善後は検査 (CAG、EPS) 治療 (PTCA、PMI) 別に 4 種類のパンフレットを 作成し検査の目的、方法、時間等を詳細したこ とから理解が深まり不安の軽減につながった
と考える。

検査前のパンフレットは「役に立った」とい う回答が改善前の $11.5 \%$ 対し、改善後では 69.3\%に増加している。また、パンフレットを 「良く見なかった」との回答は改善前 $7.7 \%$ あったが改善後では全患者が見たと回答して いる。パンフレットに検査室の写真などを載せ たこと、字を大きく読みやすく工夫したこと が、患者の見る意識を高めたと思われる。

パンフレットを改善した方が良いかの設問 では「はい」が改善前 61.5\%、改善後 26.9\% に減少した。これらの結果により改善後の方が 良い結果を示していることがうかがえる。ま た、パンフレット改善によりスタッフ間での説 明が統一でき、一定の情報が提供できるように なった。

\section{《まとめ》}

(1)心蔵カテーテル検査の新パンフレット作成 前後の患者のアンケート調查を行なった。 (2)新パンフレットを使用し、オリエンテーショ ンを行なった結果、検査、治療に対する患者 の理解が深まり、不安の軽減につながった。 
2G28 ナースコールの実態調查と患者の満足度調查

㸝

馳 修子、小笠原秀子、須賀良子

（総合病院土浦協同病院 内科病棟）

患者満足度・ナースコール

はじめに)

ナースコールは、患者が何か用事のある時 に看護婦を呼ぶための道具である。これまで 看謢婦はナースコールに頼りきって仕事をし てきたと言える。ナースコールと患者の対応 を患者満足度の一つの目安と考元、実態調查 と意識調查を行った。その結果、患者個々の ニードは満たされているとは言えなかった。 その反省を踏まえ、看護方式を変更し、べッ ドサイドケアの充実がはかれるようになった 為 さらに調查を重ね、比較検討した。その 結果、ナースコールの減少、患者満足度の充 足、看護婦のナースコールに頼らない意識の 向上をみたので報告する。

I 研究期間及び研究方法

1. 研究期間

平成 8 年 5 月 10 日 平成 9 年 3 月 31 日

2. 研究対象

上記期間入院中の患者及び病棟看護婦

3. 研究方法

1)ナースコールの実態調査

2)患者及び看護婦の意識調查

\section{II 結果及び考察}

実態調査では、図1のように、看護様式の 変更により、受け持ち看護婦としての意識の 向上がみられ、コールの回数は減少した。二 一ド別では、点滴、吸引依頼は減少したが排 泄や身体的苦痛は変化はなかった。今後さら に、記録の向上をはかり、日々のショートカ ンファレンスを活用し、個々の情報を交換し

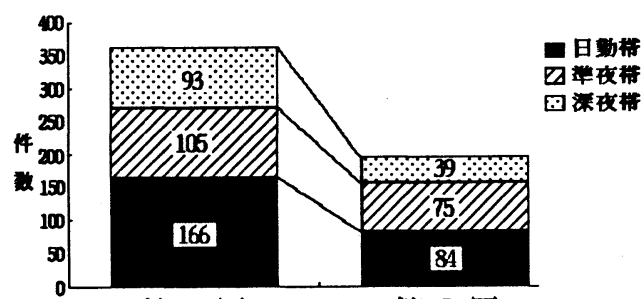

第 1 回

第 2 回

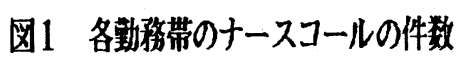

合うことで、排泄介助、身体的苦痛への先取 りした援助ができると考える。その他の内分 けは、水枕の交換、「ちょっと話を聞いて。」 「さみしいの。」などであった。患者の背景 をよくくみ取り 患者の精神的安定をむたら すことす看護ケアであると自覚し、対処した いと考える。 アンケートでは、看護婦の対応がよかった、 用事ははたされたと答えている。看護婦アン ケートでは、コールを押す前に先回りするこ とでケアが充実し満足度す得られると答えて いる。固定チームナーシングから固定チーム 受け持ち制としたことで良い結果につながっ たと考える。

\section{まとめ}

今回、看護方式の変更及び、ナースコール と看護婦の対処から、患者、看護婦の満足度 を考えてみた。患者のニーズ、看護婦の二ー ズを考えながらケアすることで、看護婦サイ ドのスケジュール調整もでき、より効率もよ くなると気付いた。今後む、基本的な私たち の看護の姿勢を見直していきたいと思う。 
$2 \mathrm{G} 29$ ナースキャップの污染状況

鎌田千鶴 丸山記代子 村瀨美代子 森田礼子 安藤恭子 池田みどり 江口由希美 岩本香苗 鈴木元美 阪口浩美

(愛知県 愛北病院)

常在菌, ナースキャプの污染, アンケート調査

\section{【はじめに】}

ナースキャップは白衣と比べ, 交換頻度が 少ないのではないか, という点から, どの程 度污染されているかに興味を持った。

\section{【結果】}

1〜3週目までは経時的にコロニー数が増 え, 3〜4週目で急にコロニー数が減ってい る。キャップ中央からの菌の検出が多い。 検出された菌はC N S 37\%，グラム陽性菌31 $\%$ ，ブドウ糖非発醉グラム陰性杆菌 $10 \%$, グ ラム陰性杆菌 $5 \%$, グラム陰性球菌 $5 \%$, ミ クロユッカス $5 \%$, 真菌 $5 \%$, 黄色ブドウ球 菌5\%であった。アンケートの結果より,ナ 一スキャップの交換頻度は 2 か月以内と答え た人が54\%をしめ, 次に 1 か月以内と答えた

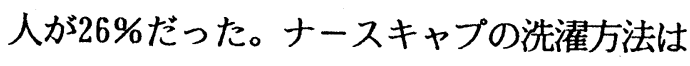
$80 \%$ 外部業者に出している。ナースキャ ップの保管場所は $58 \%$ の人がロッカー, $24 \%$ の人が寮の部屋で保管している。MRS Aの 病室に入室後, ナースキャップにアルコール

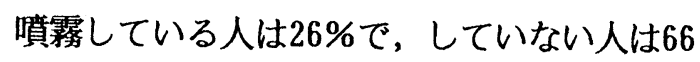
\%と多く見られた。

\section{【考察】}

ナースキャップのコロニー数は, 2 週から 3週で增えていることから，2週間以内に交 換したは方がが良いといえる。ナースキャッ プ中央部からの菌の検出が多いことは, ナ一 スキャップ着脱時に看護婦の手指が触れやす いことや, 平面であるため, 落下細菌が付着 しやすいことが考えられる。また，3週から
4週目にコロニー数が減少している点につい ては, 細胞の分裂, 增殖の特徵である誘導期 がこの時期に当たっていたのではと考えられ る。

検出菌はすべて, 院内感染に関与するといわ れる菌である。

CNSは皮膚，口腔，消化管，尿道などの常 在菌で, 全体の37\%検出されていることから モーニングケア, 排尿介助, シーツ交換など にたずさわった看護婦が手洗いをせずにナー スキャップに触れていると考えられる。 アンケートの結果より,ナースキャップの交 換頻度は 2 か月と, 白衣に比へ長期に使用し ていることから, ナースキャップの細菌污染 に対する関心の低さが考えられる。

\section{【おわりに】}

我々は, 今回の研究により,ナースキャッ プはの污染の実態を把握し，ナースキャップ の交換は 2 週間以内で行うことが良いという ことを知ることができた。また，ナースキャ ップの污染度に対する看護婦の関心の低さを 知ることができた。 


\section{G30 当院における皮膚科外来の患者指導について 熱傷患者の家庭に於ける処置法のパンフレットの作成}

イトウ カココ

愛知県厚生連海南病院 外来看護部 ○伊藤加代子 渡辺ゆう子 半田洋子 住田久美 伊藤浩美 佐藤達子 位田春代 皮膚科 矢野克明

\section{【はじめに】}

皮膚科領域の治療としては, 外用療法がき わめて重要であり薬剂を毎日交換することが 効果的であるため、毎日の通院が患者には、 非常に負担である。

そのため口頭指導にて家庭でのガーゼ交換 を実施してきたが十分な効果が得られぬため 今回、皮膚科外来を受診した熱傷患者の実態 を調査し、その中で熱傷 II 度を対象に衛生的 で効果的な処置方法を確立するために研究し たので報告する。

\section{【研究方法】}

期間 平成 8 年 6 月から 10 月

対象 熱傷 II 度の患者

手順 (1)当院皮膚科外来における熱傷 II 度の 患者調查

(2)聴き取り調査

(3)貼布ガーゼの細菌検査 (平成8年 10 月)

(4)パンフレットの作成、評価、改善

\section{【結果及び考察】}

当院での熱傷患者を平成 8 年 1 月〜 10 月ま で調查した結果 87 名であった。年齢別にみる と 9 才以下が 42 名と約 5 割を占め、その中で も 5 才以下は 33 名と幼児の比率が高い。

原因別では、どの年代にも共通した熱湯に よる受傷が多くポットの湯や調理中の鍋の湯 入浴中のシャワー等であった。

ラーメン、花火、バーベキューなど、39才 以下にみられ年齢的な特徵といえる。また、 今後もアウトドアーブームにより増加すると 思われる。

その他として靴底を介してのものや直射日光 による受傷があった。

以上の結果より判断して夕食時間帯や休日
の受傷者が全体の $64 \%$ 占めることも納得 できる。

今まで患者に対して家庭でのガーゼ交換を 口頭指導していたが消毒ガーゼを使わないで 家にある日本手ぬぐいやリント布を用いてい る人があったり、軟膏をのばすのに手指やへ ラ、スープン等を使い「このくらいの厚さに」 と見せて指導していたが、全体的に薄く、剥 がす時に痛みや出血を伴う場合があった。

そこで家庭での衛生的な処置を検討するた め、患者が貼布していたガーゼの細菌検査を 行ったところ幸いにも全例陰性であった。

以上の事から在宅での正しい消毒、軟高処 置を徹底させるためのパンフレットを作成し 高い評価を得た。

\section{【おわりに】}

患者指導の充実により自宅での処置が改善 された。今後は、受傷後皮䖉科外来受診まで の正しい応急処置の仕方を啓蒙していくこと が必要である。
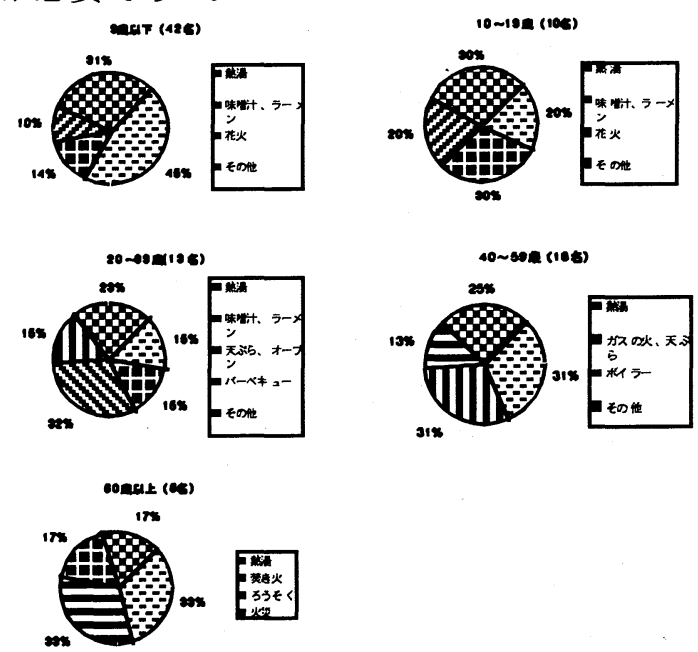

図 1 ; 熱傷 II 度患者実態調査 